\title{
COVID-19 and Disruption in Management and Education Academics: Bibliometric Mapping and Analysis
}

\author{
Margarida Rodrigues ${ }^{1}$, Mário Franco ${ }^{1, *(1)}$ and Rui Silva ${ }^{2}$ (I) \\ 1 CEFAGE-UBI Research Center, Department of Management and Economics, University of Beira Interior, \\ Estrada do Sineiro, 6200-209 Covilhã, Portugal; mmmrodrigues@sapo.pt \\ 2 CETRAD, Universidade dos Trás-os-Montes e Alto Douro, 5000-801 Vila Real, Portugal; ruisilva@utad.pt \\ * Correspondence: mfranco@ubi.pt
}

Received: 21 August 2020; Accepted: 4 September 2020; Published: 8 September 2020

check for updates

\begin{abstract}
COVID-19, What to do now? This issue has had devastating effects in all domains of society worldwide. Lockdowns, the lack of freedom and social distancing meant the closure of a country's entire activity. Having effects at all levels, beside incalculable ones in health, it is argued that scientific activity in education, business, economics and management suffered some of the most drastic impacts of this pandemic. This study aims to map the scientific literature in these areas in the context of COVID-19 and analyze its content through bibliometrics, which made it possible to highlight the scarcity of studies on the topic, namely empirical studies on the effects of this pandemic on scientific research and teaching/education. The results show there is a lack of peer-reviewed publications on this topic, with the studies covered (93) via the threads used revealing only 28 articles coming within the proposed objective. The bibliometrics corroborates that shortage. Finally, the contributions and implications for theory and practice are presented, followed by the limitations and suggestions for future research.
\end{abstract}

Keywords: COVID-19; online education; scientific production; academics; SLR

\section{Introduction}

The coronavirus, or COVID-19, was first detected in December 2019 in Wuhan, China, but only on 11 March 2020 did the World Health Organisation (WHO) declare that this had rapidly become a world pandemic, the first time a disease caused by a coronavirus had been considered as such [1]. In this scenario, COVID-19 had a major impact on public health, leading to an exponential growth of research in the field of medicine. For example, Di Gennaro et al. [2] developed a narrative review of COVID-19 and Asadi et al. [3] studied its transmission. Haleem et al. [4] identified 18 areas of research standing out in the context of the COVID-19 pandemic, where the field of economics is group 5, the topics addressed being the supply chain, travel and tourism, market closure, loss of income, economic recovery, poverty and hunger. However, a study to be published shortly by Myers et al. [5] shows that researchers report a relevant decline in the time spent on research, despite the number of hours spent on research being heterogeneous depending on the field of study (and depending on whether the field requires research in laboratories) and on gender. This has suggested that there is an atypical dimension with an impact on the hours spent on childcare by gender, which means that the pandemic has affected scientific human capital and could mold the scientific responses to the effects of the pandemic on science [5]. Also in terms of education, Kamal [6] studied teaching and COVID-19 in Brazil, arguing that distance education has reached students during the pandemic, thanks to the evolution of technologies and their multidimensional ways of being used. However, Carmo and Franco [7] show that in this teaching 
typology that teachers must accompany, guide, motivate and assess their students in a virtual learning environment. This means that teachers' competences must go beyond everyday ones to include digital competences, the management of non face-to-face contact, flexibility and a mastery of online teaching, where digital interactivity has become the main way to create and transfer knowledge [8].

In addition to an exponential adaptation to a new reality that is widespread for all teachers and the rest of the scientific community, the total lack of knowledge about the coronavirus in all scientific areas triggered signs of chaos and an unprecedented global crisis. However, crises are understood as opportunities for the generation of new scientific knowledge, so it is argued that chaos theory [9] theoretically fits the study presented here. This means that chaos allows us to establish a standardization oriented towards an apparent disorder, as a consequence of several uncertainties (e.g., economic, social, health or information uncertainties) [10]. Consequently, the current pandemic crisis is characterized by the butterfly effect postulated by chaos theory, since an infinite change in an initial state can produce unexpected results [11]. In the same line of thought, Murphy [12] argued that chaos theory is a suitable framework for crisis situations, given that these are a sequence of events that over time assume increasing volumes and complexities, with dynamics similar to a chaotic and disorderly system.

For society in general and the academic community in particular, this pandemic is a new and completely unknown subject, where the frontiers upstream and downstream are hazy, which does not detract value from a mapping of the topic in the above-mentioned areas of research. This line of thought provides the intrinsic motivation to embark on a conceptual study on this topic and to bridge the existence of the limited number of studies in these areas, given the exponentiality of studies in the health field. This motivation is further supported by the importance that scientific research and education plays in showing how to deal with this pandemic crisis and the post-COVID-19 era, since advancing knowledge on this topic will allow for constructive learning with a disruptive experience and better adaptation to the abnormal future, which is the main added value of this study. Consequently, and from a management perspective, it is important to identify academics' scientific production on education, management of business and similar areas, and how teaching institutions have adapted to the abnormal situation of lockdown in society as a whole. Therefore, the aim of this study is to map and make a bibliometric analysis of publications in the above-mentioned areas of investigation associated with scientific research and education. In other words, it is intended to systematize the scientific literature produced in 2020 on the topic of education and academic research in a pandemic environment COVID-19, through a systematic review of the literature. The operationalization of this review resides in the definition of search strings, of eligibility criteria, whose final basis will be subject to a descriptive analysis and to a bibliometric analysis by the RStudio software. It is crucial to fulfil this objective in order to bring critical aggregate value to a completely unknown topic and allow scientific knowledge to evolve rather than stagnate [13-19] and to understand its scope [20]. In addition, content analysis of all the documents included in this study will be presented.

The main contribution of this article lies in identifying the topics most studied in 2020 in the context of the COVID-19 pandemic from a management perspective. Studies here are scarce, with Myers et al. (2020) stating that the areas of education, business and management have been covered to some degree, and others have been excluded.

Then, the methodology (Section 3) is presented, which includes the definition of the strings for data collection, the eligibility criteria and the methodological procedures. The results include a descriptive analysis of the 93 selected documents and the respective content analysis, which allowed the identification of two main lines of research and their ramifications (Section 4). After this qualitative mapping, the bibliometric review (Section 5) is shown, which determined the existence of 3 clusters through factorial analysis and which confirms the lines of research identified in Section 4. Finally, the conclusions are presented, the main contributions, recommendations, limitations and future leads. 


\section{Synopsis of Literature}

COVID-19 occurred at a time of hyper-connectivity, reinforcing the importance of communication at various levels [21], for example, in the closing of schools [22] which led to face-to-face teaching changing to distance learning [23], and the cancellation of international research conferences [24], which are so important for academics and researchers to present their recent work on a given topic. In addition, besides the dramatic changes to their income, researchers had very limited use of traditional workplaces during this time, as most institutions suspended face-to-face activities [5].

This means that the suspension of face-to-face classes and the closure of Higher Education Institutions (HEIs) [25] was seen as a means to mitigate the spread of infectious diseases and avoid chains of transmission [26-28], as was the abrupt switching to online classes [29]. On the other hand, this caused abnormal changes in people's daily lives [30], including for higher education teachers, researchers and students [31]. This abnormality in the way of teaching and researching in a COVID-19 environment led to a process of relearning by all interested parties, which should be understood as a positive opportunity for change [32], supported for resilience, institutional and technological support by Strielkowski [33]. In addition, Myers et al. [5] stated that researchers have devoted less hours to research activities, which vary according to research areas and gender. However, the little research on teaching and research in the context of COVID-19, showed that resilience is a necessary condition to face this virus, namely for academics [34,35], and that this virus causes anxiety, stress [36], pessimism [37] and severe effects on research [38,39]. This pandemic reflects a challenge for researchers who have had to adapt to restrictions on access to their workplaces [31,40], performing their research duties while at home with the family [40]. The educational policies of the HEIs have also been involved in strategies that guarantee the continuity of the education system and which are characterized by several vectors, such as the availability of virtual platforms, digital content and the eventual training of teachers, especially in developing countries. In view of the imposed blockade and inherent confinement [23], requiring the definition of contingency plans [34], which must include equality and continuity of access to the resources necessary for the pursuit of the mission of teaching and research [23], without neglecting the significant educational, psychological, social and economic impacts on everyone's life, did not end with the provision of continuity of learning, which represents yet another challenge for these institutions [41]. This brief synopsis showed that the existing studies do not include any systematic review, and most of these existing studies are descriptive. Therefore, in the following sections, this gap is closed.

\section{Methodology}

Carrying out a systematic literature review (SLR) means adopting stages that can be replicated, and the procedures must be transparent in all of them [42], so that the final result can be understood as critical added value [19]. Specifically, this critical aggregation should produce a descriptive summary of the literature on the topic analyzed and identify gaps and emerging directions for future research [19]. In particular, this method is based on transparency in data collection and definition of the criteria for selecting documents [43]. However, in order to achieve the required transparency, it is essential to follow the steps defined by Tranfield, Denyer and Smart [27] and by Xiao and Watso [28], which are: definition of the objective, protocols to be followed, research in the databases of literature, definitions of inclusion and quality eligibility criteria, data extraction, synthesis of the extracted data and its analysis and discussion.

Scientific mapping of the topic of analysis was performed through the bibliometric review [13-18,44], this bibliometric analysis being a statistical method allowing assessment of the qualitative and quantitative coverage of a given area of interest [20]. This analysis was carried out using Bibliometrix software [45], which joins a set of tools for exclusive processing of all the data about the publications selected for analysis. This process produces different matrices (e.g., about authors, number of publications, networks, couplings) [46], which are preceded by the normalization of similarity of publications [45]. Aria and Cuccurullo (p. 963) underlined that "the existence of 
substantial, effective statistical algorithms, access to high-quality numerical routines, and integrated data visualization tools are perhaps the strongest qualities to prefer $\mathrm{R}$ to other languages for scientific computation." Bibliometrix is a package for bibliometric analysis written in R. R is an ecosystem software meaning it operates in an integrated environment consisting of open-libraries, the open-algorithm, and open-graphical software."

\subsection{Data Collection and Eligibility Criteria}

It is therefore fundamental to define the criteria and key-words to be used in the process of searching for and specifying documents [47] to ensure an appropriate connection between the main topic and sub-topics and the inherent descriptive analysis [48].

It is also important to mention that this study used two online databases-Web of Science (WoS) and Scopus-widely recognized by the scientific community [49], but only the search of Web of Science (WOS) returned results. It should also be noted that WOS includes thousands of academic publications and bibliographic information about authors, affiliations and citations, with high scientific recognition in the academic world.

From the above, Table 1 shows the stages followed in this study, according to Tranfield, Denyer and Smart [50] and Xiao and Watso [51].

Table 1. Stages of the systematic literature review (SLR).

\begin{tabular}{cc}
\hline Stages & Description \\
\hline Formulating the issue & $\begin{array}{c}\text { Mapping and bibliometric analysis of the publications studied in } \\
\text { management and education }\end{array}$ \\
Research protocol & $\begin{array}{c}\text { String 1: "covid 19" or "coronavirus" and "scientificproduction" } \\
\text { String 2: "covid 19" or "coronavirus" and "distanceeducation" or } \\
\text { "online education" or "schoolclosures" or "distancelearning" } \\
\text { String 3: "covid 19" or "coronavirus" and "academics" }\end{array}$ \\
\hline Data search & $\begin{array}{c}\text { WOS (26/5/2020) } \\
\text { Eligibility criteria }\end{array}$ \\
$\begin{array}{c}\text { String 1 and 3: Categories of Web of Science = (business finance or } \\
\text { management or economics or education educational research) and } \\
\text { document types = (article or review) }\end{array}$ \\
$\begin{array}{c}\text { String 2: categories of Web of Science }=(\text { business finance or } \\
\text { management or economics or education educational research) and } \\
\text { document types = (article or review) and years of publication } \\
\text { (Limited to 2020, as only research following the emergence of } \\
\text { COVID 19 is of interest) = (2020) }\end{array}$ \\
\hline Data extraction & $\begin{array}{c}\text { For Excel and Bibtex format } \\
\text { Analysis and synthesis of results }\end{array}$ \\
\hline Discussion of the results & Qualitative (descriptive) and quantitative (bibliometrics) \\
\hline
\end{tabular}

\subsection{Methodological Procedures}

The operationalization of stages 1 to 5 , i.e., the methodological procedures, are presented in Figure 1.

The requirement followed in the data collection and the application of the eligibility criteria led to the elaboration of Figure 1, which shows the careful way in which the final database was obtained $(n=93)$. The procedures shown here are in accordance with those followed in several studies of systematic and bibliometric nature [32]. Based on Figure 1, the following sections show stages 5 and 6 as described in Table 1. 


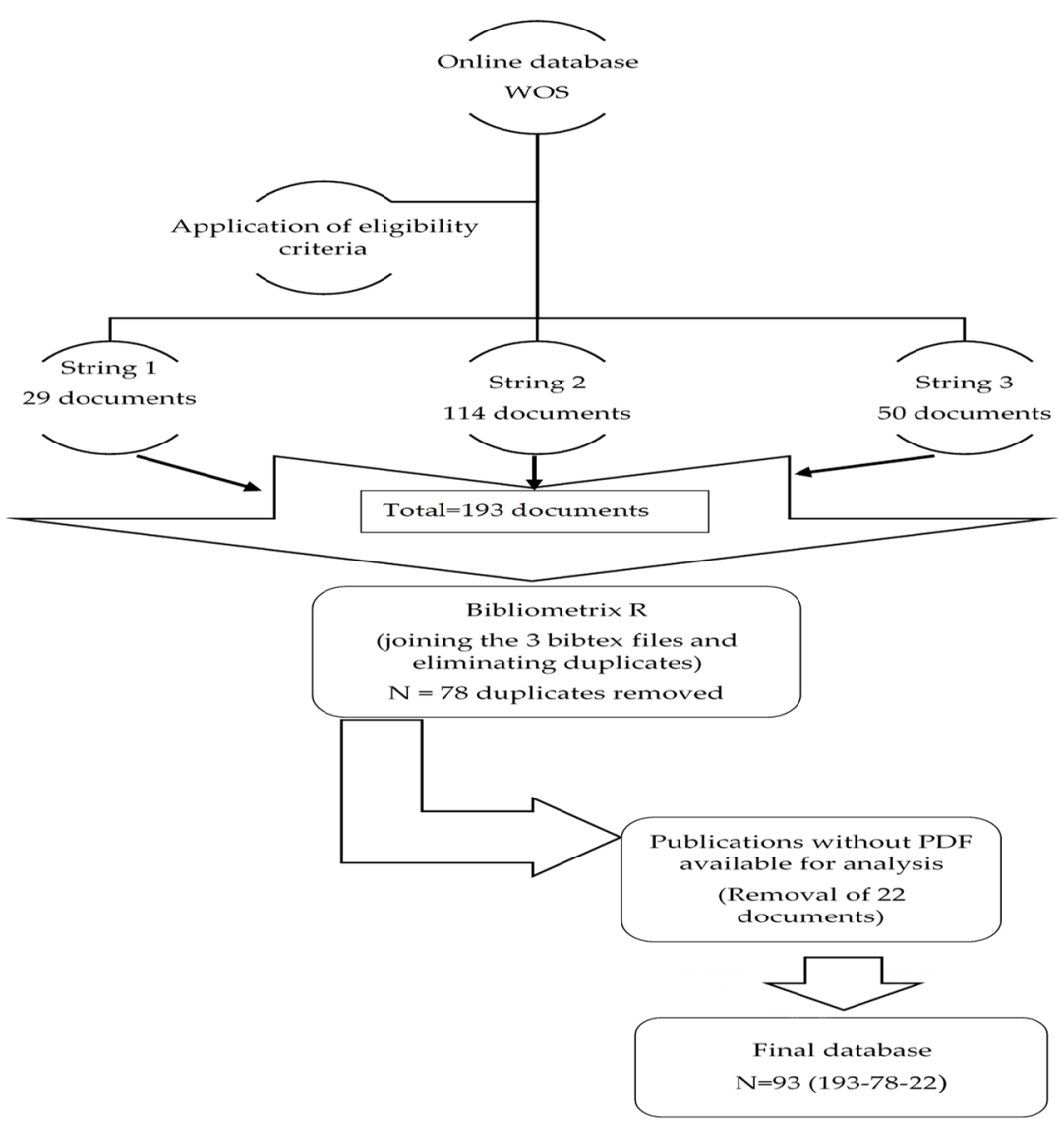

Figure 1. Methodological procedures.

\section{Mapping and Qualitative Analysis}

The mapping of the documents included in the final database was summarized by Bibliometrix $\mathrm{R}$ with the information considered relevant, as shown in Table 2.

Table 2. Main information $(n=93)$.

\begin{tabular}{cc}
\hline Items & Results \\
\hline Sources (Journals, Books, etc.) & 48 \\
\hline Documents & 93 \\
\hline Average years from publication & 0.0133 \\
\hline Average citations per document & 0.1067 \\
\hline References & 2813 \\
\hline Authors & 202 \\
\hline Authors of single-authored documents & 17 \\
\hline Authors of multi-authored documents & 185 \\
\hline Documents per Author & 0.371 \\
\hline Co-Authors per Document & 2.69 \\
\hline Collaboration Index & 3.19 \\
\hline
\end{tabular}

A reading of this table reveals that various articles have been published recently (during 2019/2020) with citations (0.1067) and that the collaboration index rate between authors is 3.19. In addition, this search covered 48 scientific journals with 202 authors using 2813 bibliographic references. Among the articles contributing to the average citations per document (0.1067), the main 
ones standing out are those by Ivanov [52], analyzing the possible impacts of COVID-19 on supply chains through the simulation of a case with the limitations of this pandemic (citations in $2020=15$ ), that of Dwyer and Walsh [53] exploring distance learning and the importance of critical thought; Herodotou et al. [54] notably studied the benefits of adopting Predictive Learning Analysis in online higher education. Only the article by Ivanov [52] was found to come within the COVID-19 context.

As for the country of origin of the 202 authors, it is important to compare that with the respective numbers of COVID-19 in that country (Data obtained from WHO on 27/5/2020 (https: //covid19.who.int/). The USA (40 authors) stands out, having 1,63410 confirmed cases; Ukraine (32 authors) has 21,584 confirmed cases; Brazil (17 authors) has 374,898 cases. Strangely, China, with 84,544 confirmed cases, only accounts for 11 authors. Analysis of these data reveals the interest of academics in these countries in contributing scientific evidence to understanding and addressing the effects of the global lockdown caused by the pandemic; even if research at large now focuses mainly on medicine and related areas, education, business, economics and management researchers are still active in their research, whether it is related to COVID-19 or not. In the case of China, the country where the pandemic began, few authors appear in the final database analyzed, perhaps because researchers' concerns have been mostly directed towards medicine.

Finalizing this descriptive analysis, the journal with most publications was Information Technologies and Learning Tools $(n=8)$, which has no impact factor (SJR) and is from Ukraine, which is logical given the number of authors originating in this country (32).

\section{Content Analysis}

Next, and also crucial in mapping the literature on a topic is content analysis of the 93 documents in the final database. This analysis aimed to identify the sub-topics studied, the objectives and the documents that are indeed related to COVID-19 in the areas of research referred to. This mapping implied integral reading of the 93 documents, in order to summarize their objective, determine the study typology, identify the sub-topic and finally identify the general conclusions. These studies were found to be of various typologies, namely: conceptual, empirical, exploratory and descriptive. Furthermore, quantitative and qualitative methodologies were used in different contexts, and sometimes jointly. However, the qualitative methodology was especially relevant, since this is a phenomenon with particular aspects, with this type of method allowing: (1) the direct source of data to be the natural environment and the researcher as the main agent involved in data collection; (2) the data gathered to be essentially of a descriptive nature; (3) researchers more interested in the process itself than in the results; (4) data analysis being performed inductively, and (5) the researcher being interested mainly in trying to understand the meaning participants attribute to their experiences $[55,56]$. This emphasis on qualitative research demonstrates that COVID-19 is an unknown phenomenon without precedents, where only quasi-experimentation can produce positive initial results, even if they have to be supported subsequently by quantitative research.

Finally, this content analysis identified two main sub-topics, namely: (1) Online education and (2) COVID-19's relation with the research areas of Education, Business, Economics and Management. Consequently, Appendix A presents the table with the content information of Group 1, as this is not related to COVID-19 but to distance learning in general, which is not the primary aim of this study but may suggest future research options related to this aim. Summarizing, this group of documents deals mainly with the competences of students and teachers, particularly regarding the technology [57] required in distance learning, the importance of involvement [58], communication [59] and interaction [60] between students and teachers, the use of technology [61], course completion rates [62] and the importance of feedback [63].

Concerning Group 2, related to COVID-19, this is analyzed in the following paragraphs. A significant number of documents related to Canada is noted, through the emergence of a special edition about agriculture, food and supply chains, among others [64,65]. However, these articles do not allow generalization of the results, as they are specific to the Canadian context. No less importantly, 
the majority of studies are exploratory and descriptive, which is understandable due to the scarcity of primary and secondary data.

As mentioned, Canada stands out in terms of (exploratory and descriptive) publications on the effects of this pandemic on management of the lockdown imposed. The effect of COVID-19 was studied in various domains and can be summarized as follows: (a) this virus altered consumer behavior in the food sector, with around $30 \%$ of the amount normally spent on eating out transferred to the retail sector [64]; (b) current agricultural policy can help farmers to manage new risks related to COVID-19 [65]; (c) pandemics are a particular risk case for the supply chain, causing a long-term interruption and a time of uncertainty, and so it was important to simulate those new impacts on the supply chain's performance following total lockdown [52]; (d) the enforced economic paralyzation reduced production [66,67], which renewed pressure on the value of agricultural land based on the duration of the recession and interest rates [67]; (e) the impact of COVID-19 on the financial wheat market has been major, causing a great volatility of prices given the uncertainty [68]; (f) food availability will be stable in the near future in the pandemic context, but there may be temporary deficits in supply and increased prices of certain food [69]; (g) this pandemic crisis requires the resilience of international supply chains, which will be neglected by consumers opting for online purchases and local chains [70,71]; (h) consumers' demand for food was changed by the pandemic (e.g., through changes in preferences, income and prices) [72], and also by the suppression of the transport system [73].

Concerning education, scientific production and academics, research related to COVID-19 is currently scarce (5 publications). Briefly, and in the area of education, Jackson et al. [74] concluded that in times of a pandemic, Twitter does not provide information in addition to other methods already used for complementary data about closed schools. This dictated the urgency to take up the challenge of setting up a new teaching method, requiring major adaptation by all involved, with the aim of using this experience of COVID-19 for future pandemics or other health emergencies [75]. The lockdown caused by the pandemic had devastating effects on Muslim women's education [76]. Concerning scientific production and academics, Wooliscroft [24] mentioned that the Conference of the Macro Marketing Society Inc. received a record amount of scientific production research, but for the first time in its history, the conference will not be held in 2020 due to COVID-19. Fernandez and Shaw [77] concluded that in times of a pandemic, good practices include a connection with people, mutual trust and clear, frequent communication between all those involved.

From a management perspective, studies are also scarce, with Grint [78] arguing that COVID-19 exposed the limits of a market-based economy and the fragilities of health systems, revealing that individuals look for charismatic or authoritarian leaders who supposedly have the management competences to defeat COVID-19 only through being positive or simply by denying evidence. The labor market also registered a major collapse. In Canada and the USA, around 50\% of workers lost income due to the pandemic, with this figure being around $25 \%$ in the UK and around $45 \%$ in China [79]. A search on this topic returned two articles on the environment, namely about the global warming caused by COVID-19 [80,81]. Another study addresses the change in consumer behavior in moving to online purchases, this being linked to the effects of fear and causing swings in purchasing trends [82]. Other relevant research includes a study about the health system's financial adaptation to COVID-19 [83], another about the economic and social measures taken to reduce transmission of the virus [84], one about price speculation in medical supplies during COVID-19 [85], while Stavins [86] describes Americans' emerging expenditure due to the pandemic in terms of credit card use.

Finally, the last articles published (4) do not relate directly to these areas and studied: perceptions of the risk of COVID-19 in Vietnam [87]; the need for health professionals to have training on how to manage ventilators [88]; the importance of continuing to be physically active during times of a pandemic [89]; and a reflection on the film The POST during the COVID-19 period [90]. Note that all these studies are published in journals in the area of business, economics and management.

This descriptive analysis allowed mapping of the topics studied, as shown in Figure 2. 


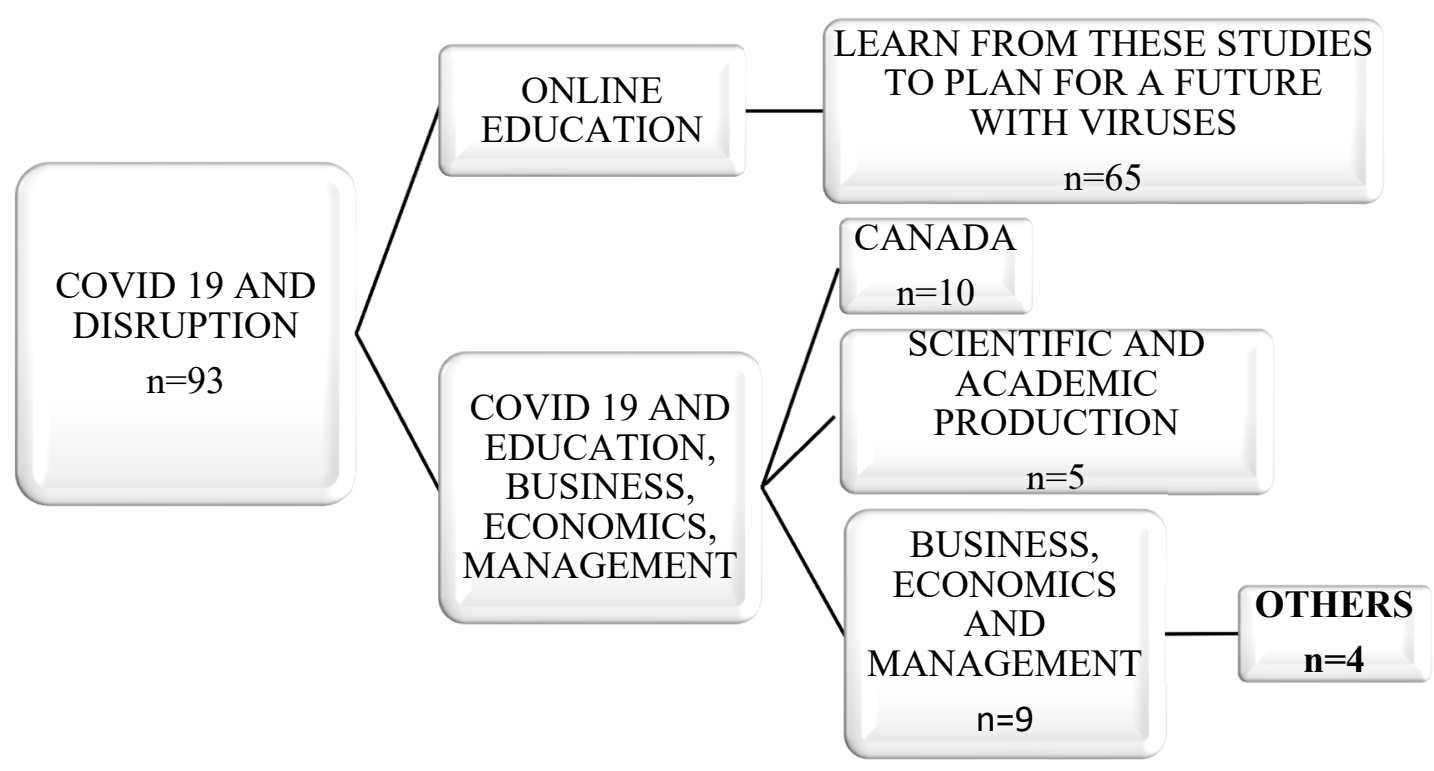

Figure 2. Mapping of the topic analyzed $(n=93)$.

This theoretical mapping shown in Figure 2 is a consequence of the 93 articles under analysis, which suggests that research on COVID-19 and the disruption it has caused in education and scientific research is still scarce, while the existing research did not go beyond the means used to bridge the absence of face-to-face classes, the importance of communication and the connection between academia. This may indicate that the lack of empirical data on this disruption interrupted the production of scientific knowledge, highlighting the weaknesses to which researchers and teachers are exposed. In short, the advancement of science is fundamental, so this mapping and content analysis has made explicit the importance of supporting the network of researchers and creating conditions so that the butterfly effect caused by chaos is not limiting research's investigative functions at a time when the abnormality will be the new normality in the future.

The above mapping suggests there are distinct groups of research, and so the following section identifies the clusters according to document titles and key words using Bibliometrix R.

\section{Bibliometric Analysis}

Network analysis has been widely used in bibliometric studies [91]. In this context, Bibliometrix $\mathrm{R}$ allows carrying out network analysis through connections between the various attributes of the database, which can be used for additional analysis [45]. These networks are analyzed to capture significant properties of the underlying research topic, and particularly, to determine the influence of bibliometric units, for example key-words and titles [45]. In accordance with the mapping above using Bibliometrix R software, Figure 3 presents the factor analysis of the 93 documents (Correspondence Analysis) in order to obtain the bipartite network of terms extracted from titles [45]. In parallel, the links between the key words of these documents are presented (Figure 4).

This figure shows that most articles in Cluster 1 do not include the term COVID-19 or coronavirus (red) in their titles. This confirms the mapping of the previous section, where articles published in the area of education studied questions and concerns related to distance learning in a situation of normality. However, the contributions of these articles reveal the students and teachers' experiences of this teaching typology and can provide synergies for the possible continuity of online classes or a mixed teaching system (face-to-face and online) in the near future. For example, the literature suggested the importance of getting around the technological anxiety [92] caused by online classes, the feeling of belonging to an academic community $[93,94]$ and feedback [63], which are new vectors for students and teachers, and also for teaching institutions. In addition, it is crucial to recognize students and teachers' remarkable adaptation to this new form of class, where physical presence was replaced 
by technology [95-97], altering the student/teacher relationship considerably [59,98,99]. Resilience was the key to this teaching typology during the pandemic, irrespective of whether teachers have the competences inherent to online teaching [57,100-102]. Cluster 2 (green), which is clearly smaller, shows that publications in management and academics' research in this area demonstrated a significant negative effect, with academic literature being one of the fields with the most harmful effects, leading to the shortage of studies on COVID-19 and its effects from a management perspective and in written research. This has to do with it being a new phenomenon, with no existing knowledge on the subject, and so management scholars' first instinct was to launch numerous questionnaires about its effects on social and other networks. It is assumed that the studies involving these questionnaires are still being elaborated on or are in the peer-review process. This means that the titles of this cluster are articles about distance learning and training and the positive and negative impacts [54,94,103-107], about leadership [77,102], about physical questions [89,101,108], about coronavirus $[78,81,84,89]$ and about management [109]. Finally, Cluster 3 (blue) represents the studies about Canada analyzed in the previous section.

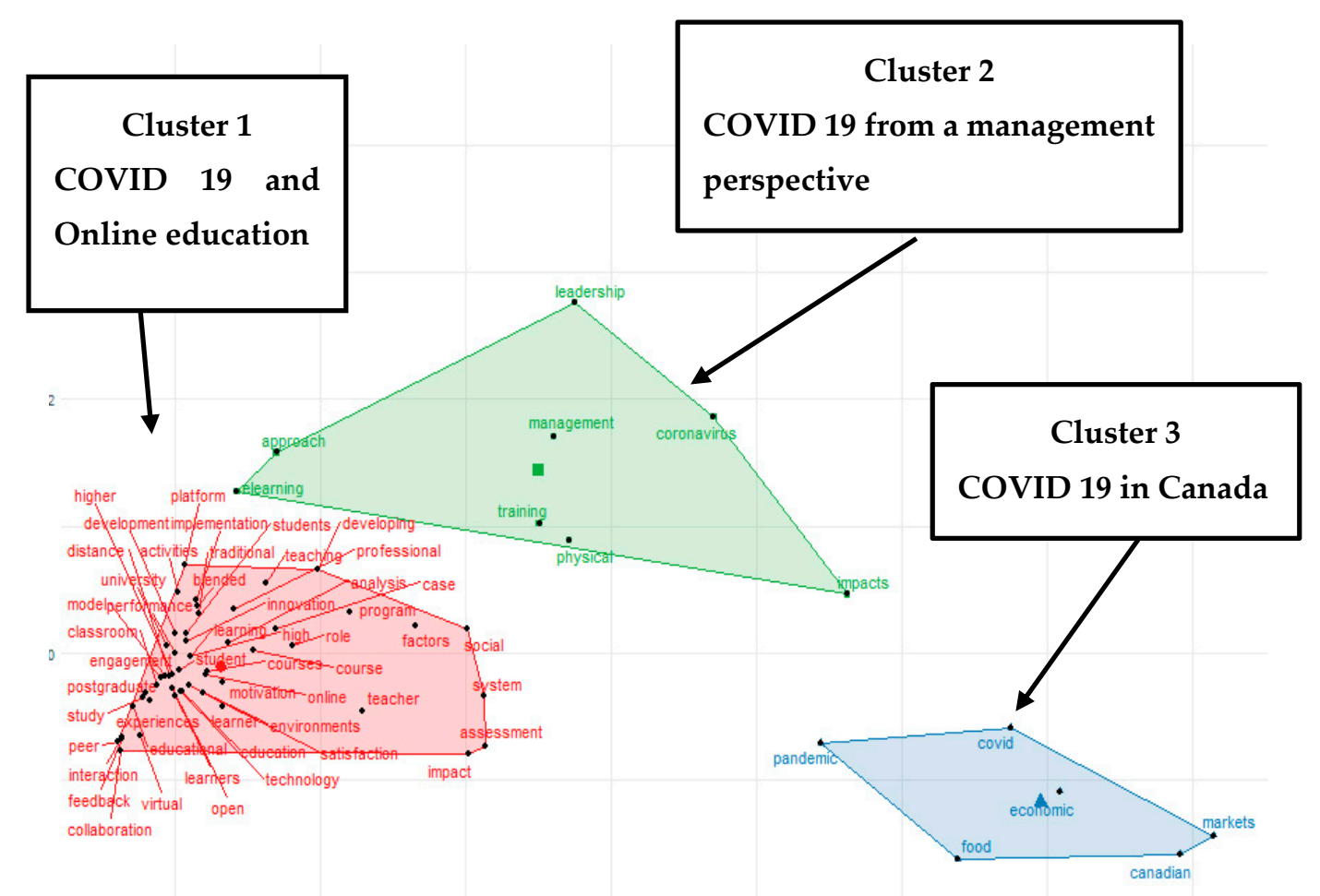

Figure 3. Factorial Analysis by titles $(n=93)$.

Based on another approach, Figure 4 shows the links between the key-words of the 93 articles, where only one association between learning and COVID-19 stands out, the research by Grint [78] connecting this virus with the type of leaders looked for in this pandemic. The disruption in research on COVID-19 from a management perspective is also confirmed.

Summarizing, the bibliometrics shows that the main topic studied was education based on online constructs and distance e-learning, with Canada standing out in studies on COVID-19 and its impacts on the country's management and economy, with the areas of business, economics and management revealing little research. 


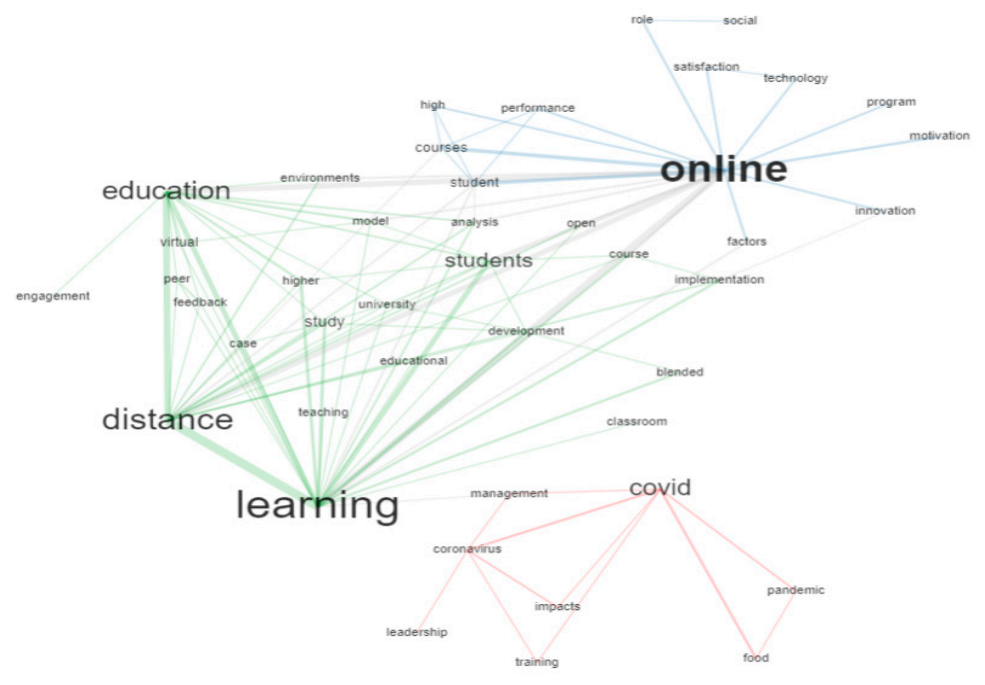

Figure 4. Network analysis by key words $(n=93)$.

\section{Conclusions and Contributions}

The development of this article was a challenge, and simultaneously an adventure into an unknown public health phenomenon with devastating effects on health, the economy, business and its management. Initially, this research highlighted that publications in the area of health grew exponentially as opposed to those dealing with education, business, economics and management, with the cause-effect relation being dictated by the urgent need to combat the pandemic. This means that in the areas of research analyzed in this article, scholars found themselves facing drastic changes in their daily academic routines associated with a different type of family life, implying major resilience in managing this. Moreover, these changes meant that research tasks diminished drastically due to the time spent on preparing and giving classes online and on assisting students at a distance, where information and communication technology was crucial.

Given this scenario of scientific literature from a management perspective, the main contribution of this conceptual article lies in showing that management and education scholars were faced with paradigmatic situations in relation to academic tasks, with a different schedule for dealing with all of them. In other words, with no freedom of choice, they turned to online teaching and learned how to work with the platforms available in order to continue to transmit programmed content to their students, and neglected research due to a lack of time.

Other contributions concern theoretical and practical implications. In terms of theory, this research produced an original study-SLR - on an unexplored topic in the area of education and management, where mapping revealed that online education and COVID-19 and management are research flows in articles that have been published in WOS up to the present date. The first topic revealed no association with COVID-19, but various studies were conducted on the pros and cons of distance learning and teaching online for all those involved. These studies give insights into the experiences felt and identify strengths and weaknesses so that this type of teaching can be of greater quality in the future. The second group was able to respond to the objective proposed, where the topic was divided into three sub-topics, namely: Canada, scientific and academic production, business, economics and management. Standing out in these sub-topics is Canada's emphasis on the effects of COVID-19 on supply chains in the food and agriculture sector, which are uncertain and still difficult to quantify. The second sub-topic addressed the closure of schools, good educational practices and the cancellation of international conferences. Finally, the third sub-topic includes a research flow on management constructs, such as the leader profile required during pandemic periods, market questions from the supply and demand perspective and environmental questions. Another theoretical implication concerns the bibliometrics used, i.e., presenting title and key-word networks, as articles from 2020 are so recently published that there was no point in examining co-citations, for example. The clustering carried out showed three 
clusters closely related to the topics and sub-topics mapped in the descriptive and content analysis, corroborating the shortage of research in the areas of analysis associated with COVID-19. Moreover, in the key-word network, only one study on leadership was linked to COVID-19.

It is also important to note that chaos theory fits as an effective theoretical support, which means that the sooner the initial state of the pandemic changes due to measures to mitigate the spread, the faster the final result changes. Applying this argument to the topic studied here, the timely closure of universities, research centers and businesses generated an apparent disorder through which the rapid way in which institutions and other entities responded in order to find a viable and efficient solution, which did not let the students continue their academic year as before, which in turn led to lost opportunities for research in progress and business survival. In other words, the butterfly worked and avoided total chaos.

Clearly, this pandemic affected domains far beyond health, although with different impacts not involving the loss of life. It must therefore be recognized that the sphere of education in general and scientific research in the areas of business, education, educational research, economics and management also experienced relevant impacts. Specifically, there has been a wide range of questionnaires published on social networks regarding all types of effects of COVID-19, to obtain robust empirical evidence that is open to generalization. However, research made in these areas has not produced any theoretical and conceptual articles on what the academic world has published, corroborating Haleem et al. [4] in the simplistic mapping of research on COVID-19, so this study provides added value in that sense.

Finally, the results of this investigation provided some recommendations for the area of education, in terms of the future. Thus, educational entities should take advantage of the opportunity given by this crisis to further digitize themselves and to offer their teachers training in online education systems, for example on how to keep students connected, communicative, participatory in these classes; teachers must rethink the way they teach their content, where the use of gamification can be an asset. Also the preparation of adequate contingency plans by the relevant entities would be an asset, so that an eventual second wave does not have an impact as severe as the first in the lives of students, teachers and investigators.

Regarding the contributions and implications for practice, there is an opportunity to define a future agenda for empirical research into all the constructs implicit in people, business, scientific research, teaching methods and other areas, which are extremely important for effective assessment of the true socio-economic impact of COVID-19 on society in general, on business management and on families' lives.

\section{Limitations and Future Avenues of Research}

Similar to other investigations, this is not without limitations. The first one concerns using only the WOS database, suggesting that future research could extend to other databases, despite this one having the greatest international recognition. For example, replicating this SLR using Google Scholar could be interesting, as a quick search of the same threads revealed a great many non-indexed articles whose content could be important, and these could be classified using Publish or Perish software, which suggests future research opportunities. Another limitation concerns the researchers' subjectivity in elaborating on the articles given the absence of publications on the topic, which suggests that empirical articles carried out in the future should set out from a new SLR to have internal and external validity.

Finally, unsurprisingly, this is fertile ground for a vast amount of future research. Therefore, some suggestions are made, and others could certainly be indicated, as none of them excludes any of he others. These are as follows: (1) a study addressing the impact of COVID-19 on scientific activities in the academic sphere; (2) research into the socio-economic impact of the pandemic on firms, due to the enforced lockdown of a country's entire economic activity; (3) investigate the socio-economic effects on families to identify their typology; (4) determine the strengths and weaknesses of online teaching for lecturers and students in higher education; (5) a descriptive and comparative study of 
the results obtained from the previous suggestions; (6) a case study about a public institution's social responsibility and citizenship in the social domain in the pandemic context; (7) another case study on how cities, through local governments, managed the pandemic.

Author Contributions: M.R. and R.S. had the initial idea for the manuscript and wrote an original draft, as well as provided the resources for the research and M.F. participated in the formal reviews and supervision. All authors have read and agreed to the published version of the manuscript.

Funding: This research was not funded.

Acknowledgments: The authors are grateful to the anonymous referees of the journal for their extremely useful suggestions to improve the quality of the paper. The authors gratefully acknowledge financial support from National Funds of the FCT-Portuguese Foundation for Science and Technology within the project «UIDB/04007/2020».

Conflicts of Interest: The authors declare no conflict of interest.

\section{Appendix A}

Table A1. Content information about Group 1-Online education.

\begin{tabular}{|c|c|c|}
\hline Authors/Year & Type of Study & Content Analysis \\
\hline $\begin{array}{l}\text { Fernandes, De Oliveira } \\
\text { Lima, Da Silva, Sales, \& De } \\
\text { Orange [109] }\end{array}$ & Empirical & $\begin{array}{l}\text { Investigating why health professionals should have } \\
\text { management competences. } \\
\text { These competences are important in providing a service of } \\
\text { excellence. Therefore, they implemented a specialized course in } \\
\text { management for oncologists, through "blended learning". The } \\
\text { results obtained show these professionals' satisfaction with } \\
\text { acquiring these additional competences, which can change their } \\
\text { behavior regarding improved health care and its costs. }\end{array}$ \\
\hline Lee [110] & Conceptual & $\begin{array}{l}\text { Critical review of open educational practices (OEP). } \\
\text { Explaining that OEP courses should be opened for the most } \\
\text { disadvantaged students. }\end{array}$ \\
\hline $\begin{array}{c}\text { Ortagus, Yang, Voorhees, \& } \\
\text { Riggs [111] }\end{array}$ & Empirical & $\begin{array}{c}\text { They aimed to determine whether the effect of the requested } \\
\text { budgets has anything to do with the total number of students } \\
\text { online at community universities. } \\
\text { Concluding that the financial structure hinders that relation, } \\
\text { although the statistical relationship between the number of } \\
\text { students and costs is not significant. }\end{array}$ \\
\hline Choi \& Choi [112] & Empirical & $\begin{array}{l}\text { Detail the benefits and challenges for teachers in online } \\
\text { international collaboration in courses in Korea and China, based } \\
\text { on students' feedback and lecturers' reflections. } \\
\text { Considered that intercultural competences were improved and } \\
\text { that lecturers face joint challenges (e.g., scheduling classes, } \\
\text { aligning course content, language) }\end{array}$ \\
\hline Saltz \& Heckman [113] & Empirical & $\begin{array}{l}\text { Whether the use of videos in online courses can increase } \\
\text { performance, as long as they are improved, specifically by using } \\
\text { the Structured Paired Activity (SPA) tool. } \\
\text { Concluding that the introduction of SPA stimulates performance, } \\
\text { since this tool raises student involvement and the effectiveness of } \\
\text { the online teaching process. }\end{array}$ \\
\hline $\begin{array}{l}\text { Ruipérez-Valiente, Halawa, } \\
\text { Slama, \& Reich [114] }\end{array}$ & Empirical & $\begin{array}{l}\text { Exploring the differences in students' behavior and preferences in } \\
\text { using the platforms of Open EDX Platform and regional Massive } \\
\text { Open Online Course (MOOC) in Jordan. } \\
\text { Concluding that the regional MOOC is more attractive, because } \\
\text { the courses pay special attention to students' interests and their } \\
\text { learning needs }\end{array}$ \\
\hline Matthews \& Kotzee [115] & Empirical & $\begin{array}{l}\text { Part-time study in the UK is in decline, and the cause of this } \\
\text { was researched. } \\
\text { Obtained evidence that fees and the increase in online education } \\
\text { platforms were and will continue to be reasons for that decline. }\end{array}$ \\
\hline $\begin{array}{c}\text { Mapp \& Boutté-Queen } \\
\text { [116] }\end{array}$ & Empirical & $\begin{array}{l}\text { Analyzing baccalaureate course programmes in social work in the } \\
\text { USA and their lecturers. } \\
\text { Concluded that most lecturers do not have training in teaching } \\
\text { online, which leads to the stressors of accreditation, time and } \\
\text { monetary matters being called into question. }\end{array}$ \\
\hline
\end{tabular}


Table A1. Cont.

\begin{tabular}{|c|c|c|}
\hline Authors/Year & Type of Study & Content Analysis \\
\hline Alanazi et al. [117] & Empirical & $\begin{array}{c}\text { Assessment of the perceived performance of students on online } \\
\text { post-graduate courses. } \\
\text { Considered that this has the predictors of the value of the task and } \\
\text { the quality of the content taught, with the relation between } \\
\text { students and technology having no significant effects } \\
\text { on performance. }\end{array}$ \\
\hline Shahzad et al. [118] & Empirical & $\begin{array}{l}\text { Analyzing MOOC based on the } \\
\text { technological-organisational-environmental approach. } \\
\text { Finding significant relations between the technological and } \\
\text { organisational constructs, as well as attitudes towards the use of } \\
\text { cloud computing. On the contrary, the environmental construct } \\
\text { did not show any relations. }\end{array}$ \\
\hline Zheng et al. [60] & Empirical & $\begin{array}{l}\text { Investigating the student-teacher relationship in online teaching. } \\
\text { The results obtained showed that students achieved better results } \\
\text { if they logged in more frequently, remaining longer online; while } \\
\text { for teachers, their influence varies according to their level } \\
\text { of qualification. }\end{array}$ \\
\hline $\begin{array}{l}\text { Fernandes, De Oliveira } \\
\text { Lima, Da Silva, Sales, \& De } \\
\text { Orange [109] }\end{array}$ & Empirical & $\begin{array}{l}\text { Investigating why health professionals should have management } \\
\text { competences. } \\
\text { These competences are important in providing a service of } \\
\text { excellence. Therefore, they implemented a specialized course in } \\
\text { management for oncologists, through "blended learning". The } \\
\text { results obtained show these professionals' satisfaction with } \\
\text { acquiring these additional competences, which can change their } \\
\text { behavior regarding improved health care and its costs. }\end{array}$ \\
\hline Lee [110] & Conceptual & $\begin{array}{l}\text { Critical review of open educational practices (OEP). } \\
\text { Explaining that OEP courses should be opened for the most } \\
\text { disadvantaged students. }\end{array}$ \\
\hline $\begin{array}{c}\text { Ortagus, Yang, Voorhees, \& } \\
\text { Riggs [111] }\end{array}$ & Empirical & $\begin{array}{l}\text { They aimed to determine whether the effect of the requested } \\
\text { budgets has anything to do with the total number of students } \\
\text { online at community universities. } \\
\text { Concluding that the financial structure hinders that relation, } \\
\text { although the statistical relationship between the number of } \\
\text { students and costs is not significant. }\end{array}$ \\
\hline Choi \& Choi [112] & Empirical & $\begin{array}{l}\text { Detail the benefits and challenges for teachers in online } \\
\text { international collaboration in courses in Korea and China, based } \\
\text { on students' feedback and lecturers' reflections. } \\
\text { Considered that intercultural competences were improved and } \\
\text { that lecturers face joint challenges (e.g., scheduling classes, } \\
\text { aligning course content, language) }\end{array}$ \\
\hline Saltz \& Heckman [113] & Empirical & $\begin{array}{l}\text { Whether the use of videos in online courses can increase } \\
\text { performance, as long as they are improved, specifically by using } \\
\text { the Structured Paired Activity (SPA) tool. } \\
\text { Concluding that the introduction of SPA stimulates performance, } \\
\text { since this tool raises student involvement and the effectiveness of } \\
\text { the online teaching process. }\end{array}$ \\
\hline $\begin{array}{l}\text { Ruipérez-Valiente, Halawa, } \\
\text { Slama, \& Reich [114] }\end{array}$ & Empirical & $\begin{array}{l}\text { Exploring the differences in students' behavior and preferences in } \\
\text { using the platforms of Open EDX Platform and regional Massive } \\
\text { Open Online Course (MOOC) in Jordan. } \\
\text { Concluding that the regional MOOC is more attractive, because } \\
\text { the courses pay special attention to students' interests and their } \\
\text { learning needs }\end{array}$ \\
\hline Matthews \& Kotzee [115] & Empirical & $\begin{array}{l}\text { Part-time study in the UK is in decline, and the cause of this was } \\
\text { researched. } \\
\text { Obtained evidence that fees and the increase in online education } \\
\text { platforms were and will continue to be reasons for that decline. }\end{array}$ \\
\hline $\begin{array}{l}\text { Mapp \& Boutté- } \\
\text { Queen [116] }\end{array}$ & Empirical & $\begin{array}{l}\text { Analyzing baccalaureate course programmes in social work in the } \\
\text { USA and their lecturers. } \\
\text { Concluded that most lecturers do not have training in teaching } \\
\text { online, which leads to the stressors of accreditation, time and } \\
\text { monetary matters being called into question. }\end{array}$ \\
\hline
\end{tabular}


Table A1. Cont.

\begin{tabular}{|c|c|c|}
\hline Authors/Year & Type of Study & Content Analysis \\
\hline Alanazi et al. [117] & Empirical & $\begin{array}{l}\text { Assessment of the perceived performance of students on online } \\
\text { post-graduate courses. } \\
\text { Considered that this has the predictors of the value of the task and } \\
\text { the quality of the content taught, with the relation between } \\
\text { students and technology having no significant effects } \\
\text { on performance. }\end{array}$ \\
\hline Shahzad et al. [118] & Empirical & $\begin{array}{l}\text { Analyzing MOOC based on the } \\
\text { technological-organisational-environmental approach. } \\
\text { Finding significant relations between the technological and } \\
\text { organisational constructs, as well as attitudes towards the use of } \\
\text { cloud computing. On the contrary, the environmental construct } \\
\text { did not show any relations. }\end{array}$ \\
\hline Zheng et al. [60] & Empirical & $\begin{array}{l}\text { Investigating the student-teacher relationship in online teaching. } \\
\text { The results obtained showed that students achieved better results } \\
\text { if they logged in more frequently, remaining longer online; while } \\
\text { for teachers, their influence varies according to their level } \\
\text { of qualification. }\end{array}$ \\
\hline $\begin{array}{l}\text { Littenberg-Tobias, Valiente, } \\
\text { \& Reich [119] }\end{array}$ & Empirical & $\begin{array}{l}\text { Exploring the relation between monetary cost and learning } \\
\text { behavior in MOOC. } \\
\text { Finding that not only the financial aspect motivates students to } \\
\text { complete the course and attend classes, with the type of } \\
\text { information and communication technology and programme } \\
\text { contents having a relevant effect on completion. }\end{array}$ \\
\hline Forde \& Gallagher [120] & Empirical & $\begin{array}{l}\text { Aiming to understand why continuous training in the online } \\
\text { model is important for nurses and what the difficulties are. } \\
\text { Proposing that nurses are concerned about their capacity to } \\
\text { respond to the standards defined by online courses. Despite } \\
\text { having experienced support from other actors they are still } \\
\text { concerned about time management. }\end{array}$ \\
\hline Danka [62] & $\begin{array}{l}\text { Conceptual and } \\
\text { exploratory }\end{array}$ & $\begin{array}{l}\text { Investigate the conclusion rates of MOOC. } \\
\text { Despite massive enrolments on these courses, completion rates are } \\
\text { low, possibly due to the lack of an appropriate method to assess } \\
\text { the evolution of learning and motivational resources. Therefore, } \\
\text { the proposal of a new theoretical framework to solve resource } \\
\text { allocation in MOOC, where a weak student-teacher } \\
\text { relationship persists. }\end{array}$ \\
\hline Anderson \& Cuttler [121] & Empirical & $\begin{array}{l}\text { Studying the adoption of e-books (open textbook). } \\
\text { Finding that adoption of this type of book is less favoured than } \\
\text { traditional books, with the cost factor having impacts } \\
\text { on this transition. }\end{array}$ \\
\hline $\begin{array}{l}\text { Elizondo-Garcia \& } \\
\text { Gallardo [122] }\end{array}$ & Empirical & $\begin{array}{l}\text { Identifying the perceptions of students on MOOC courses about } \\
\text { the student/teacher interaction and feedback. } \\
\text { The empirical evidence obtained showed that most participants } \\
\text { are willing to interact with their fellow students and participate in } \\
\text { feedback activities. They also demonstrated that peer-assessment } \\
\text { is more appropriate for that feedback. }\end{array}$ \\
\hline Harper et al. [57] & Conceptual & $\begin{array}{l}\text { Analyzing digitalization of educational services from the } \\
\text { perspective of innovation and entrepreneurship. } \\
\text { Concluding that online courses are complex and that they are a } \\
\text { new typology of innovation and entrepreneurship, due to } \\
\text { implying the creation of new designs and being included in social } \\
\text { and institutional structures that co-evolve with } \\
\text { technological changes. }\end{array}$ \\
\hline $\begin{array}{l}\text { Wilhelm-Chapin \& } \\
\text { Koszalka [100] }\end{array}$ & Empirical & $\begin{array}{l}\text { Assessing students' interactions with online course content in } \\
\text { higher education and their involvement, through Generative } \\
\text { Learning Theory. } \\
\text { Highlighting that this topic needs continuous study of the } \\
\text { connections between resources, interaction and student } \\
\text { involvement. They also mentioned that students would like to } \\
\text { have access to didactic material before online classes, do more } \\
\text { exercises and reflect on cases. }\end{array}$ \\
\hline
\end{tabular}


Table A1. Cont.

\begin{tabular}{|c|c|c|}
\hline Authors/Year & Type of Study & Content Analysis \\
\hline $\begin{array}{l}\text { Williams, Martinasek, } \\
\text { Carone, \& Sanders [123] }\end{array}$ & Empirical & $\begin{array}{l}\text { Examining the differences in perceptions between } \mathrm{F} 2 \mathrm{~F} \text { and online } \\
\text { teaching in physical education. } \\
\text { The main deduction was that online teaching brings benefits for } \\
\text { students also at the personal level, these being important for them. }\end{array}$ \\
\hline Sinacori [124] & Empirical & $\begin{array}{l}\text { Analyzing the experiences of nursing teachers in the transition } \\
\text { from the classroom to an online environment. } \\
\text { Through those experiences, it was claimed these teachers need to } \\
\text { have their training enhanced for this transition, given the need to } \\
\text { manage time, students' expectations and the pedagogical benefits } \\
\text { of those courses. }\end{array}$ \\
\hline $\begin{array}{l}\text { Kauppi, Muukkonen, } \\
\text { Suorsa, \& Takala [95] }\end{array}$ & Exploratory & $\begin{array}{l}\text { Based on the feeling of a lack of human contact in online teaching, } \\
\text { exploring the complaints/reactions of those involved. } \\
\text { Developing a pedagogical design of a course, through the benefits } \\
\text { and challenges in reaching the desired learning in online teaching, } \\
\text { emphasizing the combination of joint creation of knowledge, in a } \\
\text { virtual, flexible environment involving a multi-disciplinary group. }\end{array}$ \\
\hline Gay \& Betts [125] & Empirical & $\begin{array}{l}\text { Simulation of a real E-Meeting task in a firm on an online course. } \\
\text { The results revealed that this task can pro-actively increase } \\
\text { student involvement and retention in online courses, and so the } \\
\text { simulation was a success. Moreover, it created opportunities and } \\
\text { gave students new competences demanded by employers (e.g., } \\
\text { problem-solving, teamwork, communication, leadership, } \\
\text { time management). }\end{array}$ \\
\hline
\end{tabular}

Studying ways of making online learning effective.

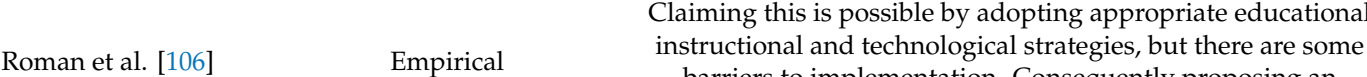
barriers to implementation. Consequently proposing an empirically tested tool to achieve that effectiveness, which is a mediator of students' motivation, cognition and behavior.

Studying the possibility of creating a human presence in online teaching.

Found it is challenging to promote interactions between all actors

Park \& Kim [96] Empirical in online teaching in the same way as in face-to-face teaching. However, the inter-activity of communication tools can create a social presence and the feeling of student satisfaction in online learning, with the effects being significant and moderated by gender.

Analyzing trends of student involvement in distance learning. The contributions of this SLR concerned the existence of efforts to encourage that involvement to take place, despite previous research having concentrated on the institutional design and educational technology, leading to a shortage of studies in the area of education systems and distance education theories. In addition, it is necessary to pay attention to properties of the media, students' characteristics, the teaching method, course design and content, innovative techniques and lecturers' competences, besides Chickering and Gamson's principles of good practices which are so important in this student involvement.

Studying the factors affecting the success of Ph.D. students in leadership on online courses.

Lee, Chang, \& Bryan [126] Concluding that relational and technological factors predict independently and interactively these students' successful learning, with it being essential to build a relation between both parties.

Obtaining proof that online teaching affects the feeling of community in relation to the institution.

Skelcher, Yang, Trespalacios, \& Snelson [94]
Empirical

From analysis of an online post-graduate course, they confirmed that feeling is very low and should be improved. As there is a proliferation of courses online, institutions should improve their forms of support. 
Table A1. Cont.

\begin{tabular}{|c|c|c|}
\hline Authors/Year & Type of Study & Content Analysis \\
\hline $\begin{array}{l}\text { Peacock, Cowan, Irvine, \& } \\
\text { Williams [93] }\end{array}$ & Empirical & $\begin{array}{l}\text { Exploring the feeling of belonging in online courses. } \\
\text { Emphasizing that this type of teaching must give value to } \\
\text { interaction, commitment, support and a learning culture between } \\
\text { both parties, since these factors influence the feeling of belonging } \\
\text { and ensure the existence of opportunities for interaction between } \\
\text { colleagues and groups. }\end{array}$ \\
\hline $\begin{array}{l}\text { Ahmed, Khan, Khan, \& } \\
\text { Mujtaba [127] }\end{array}$ & Empirical & $\begin{array}{l}\text { Studying the importance of social capital and psychological } \\
\text { factors of well-being in e-learning systems. } \\
\text { Sustained by perceived social support and the use of the media as } \\
\text { a moderator, they concluded that in online courses it is important } \\
\text { to diagnose and prevent isolation, use software that stimulates } \\
\text { social connection, to encourage personal blogs with students and } \\
\text { arrange more face-to-face meetings. }\end{array}$ \\
\hline Yavuzalp \& Bahçivan [128] & Empirical & $\begin{array}{l}\text { Studying the self-efficacy of university students on online courses. } \\
\text { Demonstrating that students' perceptions of this construct } \\
\text { regarding online learning are not affected by gender and type of } \\
\text { school. However, several psychological variables should be } \\
\text { assessed simultaneously. In addition, the relations between the } \\
\text { variables and demographic factors can be defined, and the factors } \\
\text { affecting students' success and satisfaction can be revealed. } \\
\text { Conjugating factors in this way facilitates universities' } \\
\text { interventions aiming for students' success in an online } \\
\text { learning environment. }\end{array}$ \\
\hline $\begin{array}{c}\text { Mubarak, Cao, \& Zhang } \\
\text { [108] }\end{array}$ & Empirical & $\begin{array}{l}\text { Studying low completion rates for online courses. } \\
\text { As this is a worrying topic, they built a predictive model to } \\
\text { forecast students at risk of dropping out, with the accuracy of that } \\
\text { forecast rate depending on the data on students' behavior. } \\
\text { However, these data will only be obtained on courses where there } \\
\text { is student involvement in the learning process. }\end{array}$ \\
\hline Rajagopal et al. [61] & Empirical & $\begin{array}{l}\text { Studying open virtual mobility in education. } \\
\text { Concluding that on the online courses provided, virtual mobility } \\
\text { and open education are variables affecting their quality, resulting } \\
\text { in students' acquisition of new competences, such as autonomy, } \\
\text { interaction, collaboration, an open mind and others. }\end{array}$ \\
\hline Stuij et al. [129] & Empirical & $\begin{array}{c}\text { Exploring the training and development of communication } \\
\text { competences among oncologists. } \\
\text { In this area, online training provides these professionals with } \\
\text { benefits, as it is essential they know how to communicate. In } \\
\text { addition, this type of training allows accessible forms of learning, } \\
\text { in a safe, personalized environment, especially using software that } \\
\text { can simulate a conversation with users (Chatbot) rather } \\
\text { than e-learning. }\end{array}$ \\
\hline Sedra [130] & Conceptual & $\begin{array}{l}\text { Presentation of a tool to help designers produce educational } \\
\text { content, based on the Competency-Based Approach (CBA), which } \\
\text { allows incorporation of the desired order of competences of } \\
\text { distance learning and interaction, according to an } \\
\text { orchestrated plan. }\end{array}$ \\
\hline Lengyel [104] & Exploratory & $\begin{array}{l}\text { Exploring the application of games in teaching accountancy on } \\
\text { online courses. } \\
\text { In these courses, learning is based on games linked to e-learning } \\
\text { and experimental learning, which originated a greater number of } \\
\text { active students from one semester to another, given the increasing } \\
\text { popularity of gamification. }\end{array}$ \\
\hline García-Peñalvo [131] & Conceptual & $\begin{array}{l}\text { Development of a model of reference for universities with F2F } \\
\text { classes to adapt to distance learning, including its structures. }\end{array}$ \\
\hline Lam \& Dongol [103] & Conceptual & $\begin{array}{l}\text { One of the important questions with online teaching platforms is } \\
\text { the transparency of assessment and the personalization } \\
\text { of curricula. } \\
\text { Proposal of a theoretical platform that can increase students and } \\
\text { lecturers' trust in universities' online services, regarding } \\
\text { assessment procedures and others. }\end{array}$ \\
\hline
\end{tabular}


Table A1. Cont.

\begin{tabular}{|c|c|c|}
\hline Authors/Year & Type of Study & Content Analysis \\
\hline Herodotou et al. [54] & Empirical & $\begin{array}{l}\text { Examining the adoption of Predictive Learning Analytics (PLA) in } \\
\text { online higher education courses. } \\
\text { Concluding that adoption includes lecturers' commitment and } \\
\text { involvement, creating evidence, dissemination and digital literacy. }\end{array}$ \\
\hline Dwyer \& Walsh [53] & Empirical & $\begin{array}{l}\text { Exploring distance learning in adults. } \\
\text { Highlighting the importance of critical thinking and that } \\
\text { e-learning is important for these individuals. }\end{array}$ \\
\hline $\begin{array}{c}\text { Shonfeld \& Magen-Nagar } \\
\text { [132] }\end{array}$ & Empirical & $\begin{array}{l}\text { Assessing students' intrinsic motivations in collaborative } \\
\text { programmes online. } \\
\text { Concluding that motivation is affected by students' level of } \\
\text { satisfaction, which influences their attitudes to technology. Also } \\
\text { finding that students begin to enjoy using advanced technology } \\
\text { and gain self-confidence, which diminishes technological anxiety } \\
\text { regarding online courses. }\end{array}$ \\
\hline $\begin{array}{c}\text { Hilliard, Kear, Donelan, \& } \\
\text { Heaney [92] }\end{array}$ & Empirical & $\begin{array}{l}\text { Studying students' anxiety regarding online courses. } \\
\text { Finding this is caused by students having to trust in strangers, } \\
\text { being afraid of having a negative evaluation and concern about } \\
\text { non-active group members. This anxiety diminishes with } \\
\text { decreasing uncertainty. }\end{array}$ \\
\hline Schreiber \& Jansz [63] & Empirical & $\begin{array}{l}\text { Studying the importance of feedback in distance learning. } \\
\text { Concluding that the interaction provided through feedback } \\
\text { increased the dialogue between students and lecturers, which } \\
\text { reduced the transactional distance. }\end{array}$ \\
\hline Martin [133] & Empirical & $\begin{array}{l}\text { Analysis of distance learning of languages in higher education. } \\
\text { Concluding that distance learning of languages benefits from } \\
\text { including training directed towards the pronunciation of that } \\
\text { language and helps to obtain better performance. }\end{array}$ \\
\hline $\begin{array}{l}\text { Vershitskaya, Mikhaylova, } \\
\text { Gilmanshina, Dorozhkin, \& } \\
\text { Epaneshnikov [134] }\end{array}$ & Empirical & $\begin{array}{l}\text { Assessment of students' readiness for e-learning, in a } \\
\text { management university. } \\
\text { Considering that the implementation of e-learning, based on } \\
\text { students and lecturers' perspectives and on existing problems } \\
\text { with information technology, failed due to extremely poor } \\
\text { marketing strategies and technical support. }\end{array}$ \\
\hline $\begin{array}{l}\text { Andoh, Appiah, \& Agyei } \\
\text { [135] }\end{array}$ & Empirical & $\begin{array}{l}\text { Assessing students' satisfaction with distance learning. } \\
\text { Students' satisfaction with this teaching does not depend on age, } \\
\text { gender or course content, but is closely related to the location of } \\
\text { the study centre and the semester in question. These students } \\
\text { were also impressed by the support they were given. }\end{array}$ \\
\hline Said [136] & Empiricaland descriptive & $\begin{array}{l}\text { Determining educational applications and their characteristics, } \\
\text { followed by grouping them by category. } \\
\text { This description allowed assessment of the performance of these } \\
\text { applications regarding students' use and competences. }\end{array}$ \\
\hline Kayser \& Merz [59] & Empirical & $\begin{array}{l}\text { Identifying the various types of student communication in } \\
\text { distance learning. } \\
\text { Obtaining empirical evidence of } 3 \text { types of communication among } \\
\text { students: powerful communicators, regular communicators and } \\
\text { "lone wolves". }\end{array}$ \\
\hline $\begin{array}{c}\text { Ramlatchan \& Watson } \\
\text { [137] }\end{array}$ & Empirical & $\begin{array}{l}\text { The effect of multimedia elements used by lecturers in online } \\
\text { courses and their credibility and immediacy among students. } \\
\text { Emphasizing that there can be a balance in these students' } \\
\text { perceptions, if the teaching they receive is a mix of online } \\
\text { presentations, videos and seeing the lecturer, and if the } \\
\text { presentations are good this can create an atmosphere } \\
\text { of involvement. }\end{array}$ \\
\hline $\begin{array}{c}\text { Joiner, Rees, Levett, } \\
\text { Sitnikova, \& Townsend } \\
\text { [138] }\end{array}$ & Empirical & $\begin{array}{l}\text { Exploring the effectiveness of online learning by professionals } \\
\text { throughout their life. } \\
\text { Through elaborating a comparative study of teaching pedagogies } \\
\text { regarding their effectiveness for critical thought in online work, } \\
\text { they argued that forums are more effective than direct exchange of } \\
\text { this critical sense. }\end{array}$ \\
\hline
\end{tabular}


Table A1. Cont.

\begin{tabular}{|c|c|c|}
\hline Authors/Year & Type of Study & Content Analysis \\
\hline Duran [99] & Empirical & $\begin{array}{l}\text { Study students' silence in distance learning, through the } \\
\text { phenomenological approach. } \\
\text { Concluding that students' silence can have various facets: on } \\
\text { purpose; absorption of students' silence; silence used as } \\
\text { demarcation; experiencing silence; use of deliberate, complex } \\
\text { strategies when participating; hearing in a trusting community. } \\
\text { This means this phenomenon has implications for all actors in } \\
\text { distance learning. }\end{array}$ \\
\hline Zimmerman [105] & Empirical & $\begin{array}{c}\text { Study of how to create knowledge-exchange activities in distance } \\
\text { learning. } \\
\text { The use of recorded conversations and reflections to help distance } \\
\text { learning encouraged interactions and critical dialogue among } \\
\text { participants, where the language was important for that different } \\
\text { form of learning. }\end{array}$ \\
\hline Krasnova \& Shurygin [101] & Empirical & $\begin{array}{l}\text { Assessing the competences required of lecturers to teach online. } \\
\text { Highlighting the technological competences required of lecturers, } \\
\text { despite finding a tendency for the use of information and } \\
\text { communication technology in education to facilitate learning, } \\
\text { whatever the age of users. }\end{array}$ \\
\hline Villalpando et al. [139] & $\begin{array}{l}\text { Exploratory and } \\
\text { descriptive }\end{array}$ & $\begin{array}{l}\text { Comparing the motivation statistics of mathematics students } \\
\text { involved in mixed teaching systems - F2F and F2F +e-learning - } \\
\text { Demonstrating that F2F students had better performance in } \\
\text { interest, perception and self-efficacy, while those in the mixed } \\
\text { system highlighted the financial cost associated with the choice of } \\
\text { teaching type. }\end{array}$ \\
\hline $\begin{array}{c}\text { Kilinc, Yazici, Gunsoy, \& } \\
\text { Gunsoy [107] }\end{array}$ & Empirical & $\begin{array}{l}\text { Study of distance learning in Turkey. } \\
\text { Distance learning has had positive effects in Turkey regarding } \\
\text { levels of employment (before and after), levels of income and } \\
\text { socio-economic well-being. }\end{array}$ \\
\hline Faisal \& Kisman [140] & Empirical & $\begin{array}{l}\text { Exploring the effects of using Moodle in distance learning. } \\
\text { The empirical evidence indicates that learning through an } \\
\text { educational system at a distance can simplify and accelerate work, } \\
\text { and allow more accurate and efficient work, due to this platform } \\
\text { being interactive and easy to use. }\end{array}$ \\
\hline Lee, Lim, \& Lai [102] & Empirical & $\begin{array}{l}\text { Aim to examine teacher training in advanced training at a distance. } \\
\text { These programmes last } 4 \text { years, with online classes at the weekend } \\
\text { and } 5 \text { face-to-face meetings. By assessing the performance of these } \\
\text { teachers' practical competences, they argued that they still needed } \\
\text { more training to be innovative in teaching and that their cognitive } \\
\text { taxonomy has to be emphasized. }\end{array}$ \\
\hline Jones, Lotz, \& Holden [141] & Empirical & $\begin{array}{l}\text { Application of Virtual Design Studios (VDS) during a complete } \\
\text { higher education course (3 years) and with all its students, } \\
\text { integrated in distance learning, to assess the behavior of } \\
\text { these students. } \\
\text { Concluding that VDS can support learning and social interaction, } \\
\text { leading to positive experiences and results for students, although } \\
\text { the correlation between VDS and students' success is higher in the } \\
\text { initial stages. }\end{array}$ \\
\hline $\begin{array}{l}\text { Kuznetcova, Lin, \& } \\
\text { Glassman [97] }\end{array}$ & Empirical & $\begin{array}{l}\text { Questioning the importance of lecturers' presence in } \\
\text { online teaching. } \\
\text { This presence has been considered crucial to motivate students, } \\
\text { although the use of virtual environments, with multiple users } \\
\text { simultaneously, may alter this argument. The results showed that } \\
\text { the presence of teachers encourages students' independence } \\
\text { and interactivity. }\end{array}$ \\
\hline $\begin{array}{c}\text { Laurie, Kim, José, \& Rob } \\
\text { [142] }\end{array}$ & SLR & $\begin{array}{l}\text { Systematization of the literature on the predictors of completing } \\
\text { online higher education. } \\
\text { Identifying that study strategies, academic self-efficacy, objectives, } \\
\text { intentions, institutional or university adjustments, employment, } \\
\text { the support network and the student-teacher interaction are } \\
\text { predictors of the completion rate of that teaching. Coaching, } \\
\text { corrective teaching and peer orientation are promising constructs } \\
\text { with a view to solving this problem of course completion. }\end{array}$ \\
\hline
\end{tabular}


Table A1. Cont.

\begin{tabular}{|c|c|c|}
\hline Authors/Year & Type of Study & Content Analysis \\
\hline $\begin{array}{c}\text { Prasandy, Nurlaila, Titan, } \\
\text { \& Lena [143] }\end{array}$ & Conceptual & $\begin{array}{l}\text { The differences in teaching students with hearing difficulties. } \\
\text { They argued that it is important to find innovative teaching } \\
\text { models directed to these students, and so implemented a data and } \\
\text { text mining application which produced a } 90 \% \text { improvement in } \\
\text { their performance. }\end{array}$ \\
\hline Yun \& Park [98] & Empirical & $\begin{array}{l}\text { Studying students' motivation in higher education, both } \\
\text { face-to-face and online. } \\
\text { Concluding that improved interest and environmental control are } \\
\text { significantly associated with behavioral involvement and that this } \\
\text { improvement, orientation by objectives and the behavioral effort } \\
\text { are also significantly associated with emotional and cognitive } \\
\text { involvement, moderated by students' academic level. }\end{array}$ \\
\hline Corsby \& Bryant [144] & Empirical & $\begin{array}{l}\text { Studying the effects of distance learning in Ph.D. programmes. } \\
\text { The results showed the failings of interaction when using } \\
\text { technology in distance learning, such as the quality of the } \\
\text { technology, familiarity in the classroom, the tutor's help and the } \\
\text { user's isolation. }\end{array}$ \\
\hline $\begin{array}{l}\text { Amin, Piaralal, bin Daud, } \\
\text { \& Mohamed [145] }\end{array}$ & & $\begin{array}{l}\text { Transversal investigation of the relations between the dimensions } \\
\text { of justice, university image and users' satisfaction with services. } \\
\text { The results revealed a significant relation between the dimensions } \\
\text { of justice and dissatisfaction with service recovery, in terms of } \\
\text { process and interpersonal justice. Satisfaction with service } \\
\text { recovery had a significant effect on all the behavioral results of the } \\
\text { users studied. The university image had no moderating effect on } \\
\text { the relation between the dimensions of justice and satisfaction } \\
\text { with service recovery. }\end{array}$ \\
\hline
\end{tabular}

\section{References}

1. He, F.; Deng, Y.; Li, W. Coronavirus disease 2019: What we know? J. Med. Virol. 2020, 92, 719-725. [CrossRef]

2. Di Gennaro, F.; Pizzol, D.; Marotta, C.; Antunes, M.; Racalbuto, V.; Veronese, N.; Smith, L. Coronavirus Diseases (COVID-19) Current Status and Future Perspectives: A Narrative Review. Int. J. Environ. Res. Public Health 2020, 17, 2690. [CrossRef]

3. Asadi, S.; Bouvier, N.; Wexler, A.S.; Ristenpart, W.D. The coronavirus pandemic and aerosols: Does COVID-19 transmit via expiratory particles? Aerosol Sci. Technol. 2020, 54, 635-638. [CrossRef]

4. Haleem, A.; Javaid, M.; Vaishya, R.; Deshmukh, S. Areas of academic research with the impact of COVID-19. Am. J. Emerg. Med. 2020, 5-7. [CrossRef]

5. Myers, K.; Tham, W.Y.; Yin, Y.; Cohodes, N.; Thursby, J.G.; Thursby, M.; Schiffer, P.; Walsh, J.; Lakhani, K.R.; Wang, D. Quantifying the Immediate Effects of the COVID-19 Pandemic on Scientists. SSRN Electron. J. 2020. [CrossRef]

6. Kamal, Z.N.M. Technologies for Digital, Distance and Open Education: Defining What are Those. SSRN Electron. J. 2020. [CrossRef]

7. Carmo, R.D.O.S.; Franco, A.P. DA DOCÊNCIA PRESENCIAL À DOCÊNCIA ONLINE: APRENDIZAGENS DE PROFESSORES UNIVERSITÁRIOS NA EDUCAÇÃO A DISTÂNCIA. Educ. Em. Rev. 2019, 35, 35. [CrossRef]

8. Jafarian, M.; Abdollahi, M.R.; Nathan, G.J. Preliminary evaluation of a novel solar bubble receiver for heating a gas. Sol. Energy 2019, 182, 264-277. [CrossRef]

9. Lorenz, E. On the Prevalence of Aperiodicity in Simple Systems—Global Analysis; Springer: New York, NY, USA, 1963; pp. 53-75.

10. Gleick, J.C.-A. C. de uma nova C., 4th ed.; Campus: São Paulo, Brasil, 1991; 310p.

11. Gatti, F.; Carvalho, A. Administração e Caos: Uma Estreita Relação. Rev. Ciências Gerenc. 2007, 11, 40-44.

12. Murphy, P. Chaos theory as a model for managing issues and crises. Public Relat. Rev. 1996, 22, 95-113. [CrossRef]

13. Smith, D.R. Citation Analysis and Impact Factor Trends of 5 Core Journals in Occupational Medicine, 1975-1984. Arch. Environ. Occup. Health 2010, 65, 176-179. [CrossRef] [PubMed]

14. Garfield, E. Is citation analysis a legitimate evaluation tool? Science 1979, 1, 359-375. [CrossRef] 
15. Powell, W.W.; Koput, K.W.; Smith-Doerr, L. Interorganizational Collaboration and the Locus of Innovation: Networks of Learning in Biotechnology. Adm. Sci. Q. 1996, 41, 116. [CrossRef]

16. Quinlan, K.M.; Kane, M.; Trochim, W.M.K. Evaluation of large research initiatives: Outcomes, challenges, and methodological considerations. New Dir. Eval. 2008, 2008, 61-72. [CrossRef]

17. Wolfe, A.W. Social Network Analysis: Methods and Applications. Am. Ethnol. 1997, 24, 219-220. [CrossRef]

18. White, H.D.; Griffith, B.C. Author cocitation: A literature measure of intellectual structure. J. Am. Soc. Inf. Sci. 1981, 32, 163-171. [CrossRef]

19. Mentzer, J.T.; Kahn, K.B. A Framework of Logistic Reserarch. J. Bus. Logist. 1995, 16, 231-250.

20. Geaney, F.; Scutaru, C.; Kelly, C.; Glynn, R.W.; Perry, I.J. Type 2 Diabetes Research Yield, 1951-2012: Bibliometrics Analysis and Density-Equalizing Mapping. PLoS ONE 2015, 10, e0133009. [CrossRef]

21. Кештов, М.Л.; Куклин, С.А.; Бузин, М.И.; Годовский, Д.Ю.; Хохлов, А.Р. СИНТЕЗ ИФОТОФИЗИЧЕСКИЕСВОЙСТВА ПОЛУПРОВОДНИКОВЫХ МОЛЕКУЛ Д1-А-Д2-А-Д1-СТРУКТУРЫ НА ОСНОВЕПРОИЗВОДНЫХ ХИНОКСАЛИНА И ДИТИЕНОСИЛОЛА ДЛЯ ОРГАНИЧЕСКИХСОЛНЕЧНЫХФОТОЭЛЕМЕНТОВ. ДокладыАкадемии наук 2016, 469, 319-323. [CrossRef]

22. Viner, R.M.; Russell, S.J.; Croker, H.; Packer, J.; Ward, J.; Stansfield, C.; Mytton, O.; Bonell, C.; Booy, R. School Closure and Management Practices during Coronavirus Outbreaks Including COVID-19: A Rapid Systematic Review. Lancet Child Adolesc. Heal. 2020, 4, 397-404. [CrossRef]

23. UNESCO. COVID-19 and Higher Education: Today and Tomorrow IMPACT Analysis, Policy Responses and Recommendations; UNESCO, IESALC: Paris, France, 2020; pp. 1-46.

24. Wooliscroft, B. Macromarketing the Time is Now. J. Macromark. 2020, 40, 153-155. [CrossRef]

25. Sahu, P.K. Closure of Universities Due to Coronavirus Disease 2019 (COVID-19): Impact on Education and Mental Health of Students and Academic Staff. Cureus 2020, 12, 4-9. [CrossRef] [PubMed]

26. Kawano, S.; Kakehashi, M. Substantial Impact of School Closure on the Transmission Dynamics during the Pandemic Flu H1N1-2009 in Oita, Japan. PLoS ONE 2015, 10, e0144839. [CrossRef]

27. De Luca, G.; Van Kerckhove, K.; Coletti, P.; Poletto, C.; Bossuyt, N.; Hens, N.; Colizza, V. The impact of regular school closure on seasonal influenza epidemics: A data-driven spatial transmission model for Belgium. BMC Infect. Dis. 2018, 18, 29. [CrossRef]

28. Wheeler, C.C.; Erhart, L.M.; Jehn, M. Effect of School Closure on the Incidence of Influenza Among School-Age Children in Arizona. Public Health Rep. 2010, 125, 851-859. [CrossRef]

29. Gewin, V. Five tips for moving teaching online as COVID-19 takes hold. Nature 2020, 580, 295-296. [CrossRef] [PubMed]

30. Baldwin, R.; Weder, B. Economics in the Time of COVID-19; CEPR Press: London, UK, 2020.

31. Sorokowski, A.P.; Kowal, M.; Sorokowska, A.; Lebuda, I.; Białek, M.; Kowalska, K.; Wojtycka, L.; Karwowski, M. Dread in Academia-How COVID-19 Affects Science and Scientists; Institute of Psychology, University of Wroclaw: Wroclaw, Poland, 2020; pp. 1-5.

32. Corbera, E.; Anguelovski, I.; Honey-Rosés, J.; Ruiz-Mallén, I. Academia in the Time of COVID-19: Towards an Ethics of Care. Plan. Theory Pract. 2020, 21, 191-199. [CrossRef]

33. Strielkowski, W. COVID-19 Pandemic and the Digital Revolution in Academia and Higher Education; Prague Business School: Prague, Czech Republic, 2020.

34. Dohaney, J.; De Roiste, M.; Salmon, R.A.; Sutherland, K. Benefits, barriers, and incentives for improved resilience to disruption in university teaching. Int. J. Disaster Risk Reduct. 2020, 50, 101691. [CrossRef]

35. Zanon, C.; Dellazzana-Zanon, L.; Weschler, S.; Fabretti, R.; Rocha, K. COVID-19: Implications and Applications of Positive Psychology in Times of Pandemia. Estud. Psicol. 2020, 37, 1-30.

36. Polizzi, C.; Lynn, S.J.; Perry, A. Perspective Article Stress and Coping in the Time of COVID-19: Pathways to Resilience and Recovery. Clin. Neuropsychiatry 2020, 17, 59-62.

37. Shukla, A.; Dwivedi, M. Pessimism towards Optimism: Empowering University Students amid COVID-19. Tathapi Ugc. Care J. 2020, 19, 149-159.

38. Inouye, D.W.; Underwood, N.; Inouye, B.D.; Irwin, R.E. Support early-career field researchers. Science 2020, 368, 724-725. [CrossRef]

39. Staniscuaski, F.; Reichert, F.; Werneck, F.P.; De Oliveira, L.; Mello-Carpes, P.B.; Soletti, R.C.; Almeida, C.I.; Zandona, E.; Ricachenevsky, F.K.; Neumann, A.; et al. Impact of COVID-19 on academic mothers. Science 2020, 368, 724. [CrossRef] 
40. Omary, M.B.; Eswaraka, J.R.; Kimball, S.D.; Moghe, P.V.; Panettieri, J.R.A.; Scotto, K.W. The COVID-19 pandemic and research shutdown: Staying safe and productive. J. Clin. Investig. 2020, 130, 2745-2748. [CrossRef]

41. Carver, L.B. Supporting Learners in a Time of Crisis. Adv. Soc. Sci. Res. J. 2020, 7, 129-136. [CrossRef]

42. Briner, R.B.; Denyer, D. Systematic Review and Evidence Synthesis as a Practice and Scholarship Tool. In Systematic Review and Evidence Synthesis as a Practice and Scholarship Tool; Oxford University Press: Oxford, UK, 2012; pp. 112-129.

43. Hadengue, M.; De Marcellis-Warin, N.; Warin, T. Reverse innovation: A systematic literature review. Int. J. Emerg. Mark. 2017, 12, 142-182. [CrossRef]

44. Howard, W.; Katherine, M. Visualizing a Discipline: An Author Co-Citation Analysis of Information Science, 1972-1995. J. Am. Soc. Inf. Sci. 1998, 49, 327-355.

45. Aria, M.; Cuccurullo, C. bibliometrix: An R-tool for comprehensive science mapping analysis. J. Inf. 2017, 11, 959-975. [CrossRef]

46. Ekundayo, T.C.; Okoh, A.I. A global bibliometric analysis of Plesiomonas-related research (1990-2017). PLOS ONE 2018, 13, e0207655. [CrossRef]

47. Bandara, W.; Miskon, S.; Fielt, E. A Systematic, Tool-Supported Method for Conducting Literature Reviews. In ECIS 2011 Proceedings [19th European Conference on Information Systems]; AIS Electronic Library (AISeL)/Association for Information Systems: Atlanta, GA, USA, 2011; pp. 1-13.

48. Treinta, F.T.; Filho, J.R.D.F.; Sant'Anna, A.P.; Rabelo, L.M. Metodologia de pesquisa bibliográfica com a utilização de método multicritério de apoio à decisão. Production 2013, 24, 508-520. [CrossRef]

49. Rodrigues, M.; Franco, M. Networks and performance of creative cities: A bibliometric analysis. City Cult. Soc. 2020, 20, 100326. [CrossRef]

50. Tranfield, D.; Denyer, D.; Smart, P. Towards a Methodology for Developing Evidence-Informed Management Knowledge by Means of Systematic Review. Br. J. Manag. 2003, 14, 207-222. [CrossRef]

51. Xiao, Y.; Watson, M. Guidance on Conducting a Systematic Literature Review. J. Plan. Educ. Res. 2017, 39, 93-112. [CrossRef]

52. Ivanov, D. Predicting the impacts of epidemic outbreaks on global supply chains: A simulation-based analysis on the coronavirus outbreak (COVID-19/SARS-CoV-2) case. Transp. Res. Part E Logist. Transp. Rev. 2020, 136, 101922. [CrossRef]

53. Dwyer, C.P.; Walsh, A. An exploratory quantitative case study of critical thinking development through adult distance learning. Educ. Technol. Res. Dev. 2019, 68, 17-35. [CrossRef]

54. Herodotou, C.; Rienties, B.; Hlosta, M.; Boroowa, A.; Mangafa, C.; Zdrahal, Z. The scalable implementation of predictive learning analytics at a distance learning university: Insights from a longitudinal case study. Internet High. Educ. 2020, 45, 100725. [CrossRef]

55. Yin, R. Case Study Research: Design and Methods-Applied Social Research Methods Series, 6th ed.; Sage Publications, Inc.: Thousand Oaks, CA, USA, 2015.

56. Mills, J.; Birks, M. Qualititave Methodology: A Practical Guide; SAGE Publications: Thousand Oaks, CA, USA, 2014; pp. 2-15.

57. Harper, D.A.; Muñoz, F.-F.; Vázquez, F.J. Innovation in online higher-education services: Building complex systems. Econ. Innov. New Technol. 2020, 1-20. [CrossRef]

58. Yilmaz, A.B.; Banyard, P. Engagement in Distance Education Settings: A Trend Analysis. Turk. Online J. Distance Educ. 2020, 101-120. [CrossRef]

59. Kayser, I.; Merz, T. Lone Wolves in Distance Learning? Int. J. Mob. Blended Learn. 2020, 12, 82-94. [CrossRef]

60. Zheng, B.; Lin, C.-H.; Kwon, J.B. The impact of learner-, instructor-, and course-level factors on online learning. Comput. Educ. 2020, 150, 103851. [CrossRef]

61. Rajagopal, K.; Firssova, O.; De Beeck, I.O.; Van Der Stappen, E.; Stoyanov, S.; Henderikx, P.; Buchem, I. Learner skills in open virtual mobility. Res. Learn. Technol. 2020, 28, 1-18. [CrossRef]

62. Danka, I. Motivation by gamification: Adapting motivational tools of massively multiplayer online role-playing games (MMORPGs) for peer-to-peer assessment in connectivist massive open online courses (cMOOCs). Int. Rev. Educ. 2020, 66, 75-92. [CrossRef]

63. Schreiber, B.R.; Jansz, M. Reducing distance through online international collaboration. ELT J. 2019, 74, 63-72. [CrossRef] 
64. Goddard, E. The impact of COVID-19 on food retail and food service in Canada: Preliminary assessment. Can. J. Agric. Econ. Can. D'agroeconomie 2020, 68, 157-161. [CrossRef]

65. Ker, A.P. Risk management in Canada's agricultural sector in light of COVID-19. Can. J. Agric. Econ. Can. D'agroeconomie 2020, 68, 251-258. [CrossRef]

66. Hailu, G. Economic thoughts on COVID-19 for Canadian food processors. Can. J. Agric. Econ. Can. D'agroeconomie 2020, 68, 163-169. [CrossRef]

67. Lawley, C. Potential impacts of COVID-19 on Canadian farmland markets. Can. J. Agric. Econ. Can. D'agroeconomie 2020, 68, 245-250. [CrossRef]

68. Vercammen, J. Information-rich wheat markets in the early days of COVID-19. Can. J. Agric. Econ. Can. D'agroeconomie 2020, 68, 177-184. [CrossRef]

69. Deaton, B.J. Food security and Canada's agricultural system challenged by COVID-19. Can. J. Agric. Econ. Can. D'agroeconomie 2020, 68, 143-149. [CrossRef]

70. Hobbs, J.E. Food supply chains during the COVID-19 pandemic. Can. J. Agric. Econ. Can. D'agroeconomie 2020, 68, 171-176. [CrossRef]

71. Weersink, A.; Von Massow, M.; McDougall, B. Economic thoughts on the potential implications of COVID-19 on the Canadian dairy and poultry sectors. Can. J. Agric. Econ. Can. D'agroeconomie 2020, 68, 195-200. [CrossRef]

72. Cranfield, J.A.L. Framing consumer food demand responses in a viral pandemic. Can. J. Agric. Econ. Can. D'agroeconomie 2020, 1-6. [CrossRef]

73. Gray, R.S. Agriculture, transportation, and the COVID-19 crisis. Can. J. Agric. Econ. Can. D'agroeconomie 2020, 68, 239-243. [CrossRef]

74. Jackson, A.M.; A Mullican, L.; Tse, Z.T.H.; Yin, J.; Zhou, X.; Bs, D.K.; Fung, I.C.-H.; Mph, L.A.M. Unplanned Closure of Public Schools in Michigan, 2015-2016: Cross-Sectional Study on Rurality and Digital Data Harvesting. J. Sch. Health 2020, 90, 511-519. [CrossRef] [PubMed]

75. Moorhouse, B.L. Adaptations to a face-to-face initial teacher education course 'forced' online due to the COVID-19 pandemic. J. Educ. Teach. 2020, 1-3. [CrossRef]

76. Safdar, M.; Yasmin, M.; Alvi, M.Y. COVID-19: A threat to educated Muslim women's negotiated identity in Pakistan. Gend. Work. Organ. 2020, 1-12. [CrossRef]

77. Fernandez, A.A.; Shaw, G.P. Academic Leadership in a Time of Crisis: The Coronavirus and COVID-19. J. Lead. Stud. 2020, 14, 39-45. [CrossRef]

78. Grint, K. Leadership, management and command in the time of the Coronavirus. Leadership 2020, 16, 314-319. [CrossRef]

79. Bell, D.N.F.; Blanchflower, D.G. US and UK labour markets before and during the COVID-19 CRASH. Natl. Inst. Econ. Rev. 2020, 252, R52-R69. [CrossRef]

80. Helm, D. The Environmental Impacts of the Coronavirus. Environ. Resour. Econ. 2020, 76, 21-38. [CrossRef]

81. Selby, D.; Kagawa, F. Climate change and coronavirus: A confluence of two emergencies as learning and teaching challenge. In Policy \& Practice: A Development Education Review, 30. Policy E Practice; Centre for Global Education: Belfast, Ireland, 2020.

82. Addo, P.C.; Jiaming, F.; Kulbo, N.B.; Liangqiang, L. COVID-19: Fear appeal favoring purchase behavior towards personal protective equipment. Serv. Ind. J. 2020, 40, 471-490. [CrossRef]

83. Jeyabaladevan, P. COVID-19: An FY1 on the frontline. Med. Educ. Online 2020, 25, 1759869. [CrossRef]

84. Qiu, Y.; Chen, X.; Shi, W. Impacts of social and economic factors on the transmission of coronavirus disease 2019 (COVID-19) in China. J. Popul. Econ. 2020, 33, 1127-1172. [CrossRef]

85. Evenett, S.J. Sicken Thy Neighbour: The Initial Trade Policy Response to COVID-19. World Econ. 2020, 4, 828-839. [CrossRef]

86. Stavins, J. Unprepared for financial shocks: Emergency savings and credit card debt. Contemp. Econ. Policy 2020. [CrossRef]

87. Huynh, T.L. The COVID-19 Risk Perception: A Survey on Socioeconomics and Media Attention. Economics Bulletin. AccessEcon 2020, 401, 758-764.

88. Naik, N.; Finkelstein, R.A.; Howell, J.; Rajwani, K.; Ching, K. Telesimulation for COVID-19 Ventilator Management Training With Social-Distancing Restrictions During the Coronavirus Pandemic. Simul. Gaming 2020. [CrossRef] 
89. Hammami, A.; Harrabi, B.; Mohr, M.; Krustrup, P. Physical activity and coronavirus disease 2019 (COVID-19): Specific recommendations for home-based physical training. Manag. Sport Leis. 2020, 1-6. [CrossRef]

90. Cho, Y. The Post: A token woman leader's transformation. Hum. Resour. Dev. Q. 2020, 1-5. [CrossRef]

91. Jalal, S.K. Co-Authorship and Co-Occurrences Analysis Using Bibliometrix r-Package: A Case Study of India and Bangladesh. Ann. Libr. Inf. Stud. 2019, 66, 57-64.

92. Hilliard, J.; Kear, K.; Donelan, H.; Heaney, C.A. Students' experiences of anxiety in an assessed, online, collaborative project. Comput. Educ. 2020, 143, 103675. [CrossRef]

93. Peacock, S.; Cowan, J.; Irvine, L.; Williams, J. An Exploration Into the Importance of a Sense of Belonging for Online Learners. Int. Rev. Res. Open Distrib. Learn. 2020, 21, 18-35. [CrossRef]

94. Skelcher, S.; Yang, D.; Trespalacios, J.; Snelson, C. Connecting online students to their higher learning institution. Distance Educ. 2020, 41, 128-147. [CrossRef]

95. Kauppi, S.; Muukkonen, H.; Suorsa, T.; Takala, M. I still miss human contact, but this is more flexible-Paradoxes in virtual learning interaction and multidisciplinary collaboration. Br. J. Educ. Technol. 2020, 51, 1101-1116. [CrossRef]

96. Park, C.; Kim, D. Exploring the Roles of Social Presence and Gender Difference in Online Learning. Decis. Sci. J. Innov. Educ. 2020, 18, 291-312. [CrossRef]

97. Kuznetcova, I.; Lin, T.-J.; Glassman, M. Teacher Presence in a Different Light: Authority Shift in Multi-user Virtual Environments. Technol. Knowl. Learn. 2020, 1-25. [CrossRef]

98. Yun, H.; Park, S. Building a structural model of motivational regulation and learning engagement for undergraduate and graduate students in higher education. Stud. High. Educ. 2018, 45, 271-285. [CrossRef]

99. Lee, H.; Chang, H.; Bryan, L. Doctoral Students' Learning Success in Online-Based Leadership Programs: Intersection With Technological and Relational Factors. Int. Rev. Res. Open Distrib. Learn. 2020, 21, 61-81. [CrossRef]

100. Wilhelm-Chapin, M.K.; Koszalka, T.A. Graduate Students' Use and Perceived Value of Learning Resources in Learning the Content in an Online Course. TechTrends 2020, 64, 361-372. [CrossRef]

101. Krasnova, L.; Shurygin, V. Blended Learning of Physics in the Context of the Professional Development of Teachers. Int. J. Emerg. Technol. Learn. 2019, 14, 17-32. [CrossRef]

102. Lee, M.F.; Lim, S.C.J.; Lai, C.S. Assessment of Teaching Practice Competency among In-Service Teacher Degree Program PPG. in Universiti Tun Hussein Onn Malaysia. J. Tech. Educ. Train. 2020, 181-188. [CrossRef]

103. Lam, T.Y.; Dongol, B. A blockchain-enabled e-learning platform. Interact. Learn. Environ. 2020, 1-23. [CrossRef]

104. Lengyel, P.S. Can the Game-Based Learning Come? Virtual Classroom in Higher Education of 21st Century. Int. J. Emerg. Technol. Learn. 2020, 15, 112-126. [CrossRef]

105. Zimmerman, E. Code-switching in conversation-for-learning: Creating opportunities for learning while on study abroad. Foreign Lang. Ann. 2020, 53, 149-175. [CrossRef]

106. Roman, T.A.; Callison, M.; Myers, R.D.; Berry, A.H. Facilitating Authentic Learning Experiences in Distance Education: Embedding Research-Based Practices into an Online Peer Feedback Tool. TechTrends 2020, 64, 591-605. [CrossRef]

107. Kilinc, B.K.; Yazici, B.; Gunsoy, B.; Gunsoy, G. Perceptions and Opinions of Graduates about the Effects of Open and Distance Learning in Turkey. Turk. Online J. Distance Educ. 2020, 121-132. [CrossRef]

108. Mubarak, A.A.; Cao, H.; Zhang, W. Prediction of students' early dropout based on their interaction logs in online learning environment. Interact. Learn. Environ. 2020, 1-20. [CrossRef]

109. Fernandes, R.A.M.L.; Lima, J.T.D.O.; Da Silva, B.H.; Sales, M.J.T.; De Orange, F.A. Development, implementation and evaluation of a management specialization course in oncology using blended learning. BMC Med. Educ. 2020, 20, 37. [CrossRef]

110. Lee, K. Who opens online distance education, to whom, and for what? Distance Educ. 2020, 41, $186-200$. [CrossRef]

111. Ortagus, J.C.; Yang, L.; Voorhees, N.; Riggs, S. Revenue Reconsidered: Exploring the Influence of Changes in Local and State Appropriations on Online Enrollment at Community Colleges. Community Coll. J. Res. Pract. 2020, 1-14. [CrossRef]

112. Choi, S.-H.; Choi, S.-H. Virtual short-term intercultural exchange as an inclusive educational strategy: Lessons from the collaboration of two classes in South Korea and China. J. Teach. Travel Tour. 2020, 1-18. [CrossRef] 
113. Saltz, J.; Heckman, R. Using Structured Pair Activities in a Distributed Online Breakout Room. Online Learn. 2020, 24, 227-244. [CrossRef]

114. Ruiperez-Valiente, J.A.; Halawa, S.; Slama, R.; Reich, J. Using multi-platform learning analytics to compare regional and global MOOC learning in the Arab world. Comput. Educ. 2020, 146, 103776. [CrossRef]

115. Matthews, A.; Kotzee, B. UK university part-time higher education: A corpus-assisted discourse analysis of undergraduate prospectuses. High. Educ. Res. Dev. 2020,1-16. [CrossRef]

116. Mapp, S.; Boutté-Queen, N. The role of the US baccalaureate social work program director: A national survey. Soc. Work. Educ. 2020,1-18. [CrossRef]

117. Alanazi, A.A.; Frey, B.B.; Niileksela, C.; Lee, S.W.; Nong, A.; Alharbi, F. The Role of Task Value and Technology Satisfaction in Student Performance in Graduate-Level Online Courses. TechTrends 2020, 1-9. [CrossRef]

118. Shahzad, F.; Xiu, G.; Khan, I.; Shahbaz, M.; Riaz, M.U.; Abbas, A. The moderating role of intrinsic motivation in cloud computing adoption in online education in a developing country: A structural equation model. Asia Pac. Educ. Rev. 2019, 21, 121-141. [CrossRef]

119. Littenberg-Tobias, J.; Valiente, J.R.; Reich, J. Studying learner behavior in online courses with free-certificate coupons: Results from two case studies. Int. Rev. Res. Open Distance Learn. 2020, 21, 197-200.

120. Forde, C.; Gallagher, S. Postgraduate Online Teaching in Healthcare: An Analysis of Student Perspectives. Online Learn. 2020, 24, 118-139. [CrossRef]

121. Lee, D.; Watson, S.L.; Watson, W.R. The Relationships between Self-Efficacy, Task Value, and Self-Regulated Learning Strategies in Massive Open Online Courses. Int. Rev. Res. Open Distrib. Learn. 2020, 21, $23-39$. [CrossRef]

122. Elizondo-Garcia, J.; Gallardo, K. Peer Feedback in Learner-Learner Interaction Practices. Mixed Methods Study on an XMOOC. Electron. J. E-Learn. 2020, 18, 122-135. [CrossRef]

123. Williams, L.; Martinasek, M.P.; Carone, K.; Sanders, S. High School Students' Perceptions of Traditional and Online Health and Physical Education Courses. J. Sch. Health 2020, 90, 234-244. [CrossRef] [PubMed]

124. Sinacori, B.C. How Nurse Educators Perceive the Transition From the Traditional Classroom to the Online Environment. Nurs. Educ. Perspect. 2020, 41, 16-19. [CrossRef] [PubMed]

125. Gay, G.H.; Betts, K. From Discussion Forums to eMeetings: Integrating High Touch Strategies to Increase Student Engagement, Academic Performance, and Retention in Large Online Courses. Online Learn. 2020, 24, 92-117. [CrossRef]

126. Anderson, T.; Cuttler, C. Open to Open? An Exploration of Textbook Preferences and Strategies to Offset Textbook Costs for Online Versus On-Campus Students. Int. Rev. Res. Open Distrib. Learn. 2020, 21, 40-60. [CrossRef]

127. Ahmed, S.K.; Khan, M.M.; Khan, R.A.; Mujtaba, B.G. The Relationship between Social Capital and Psychological Well-Being: The Mediating Role of Internet Marketing. Mark. Manag. Innov. 2020, 1, 40-53. [CrossRef]

128. Yavuzalp, N.; Bahçivan, E. The Online Learning Self-Efficacy Scale: Its Adaptation into Turkish and Interpretation According to Various Variables. Turk. Online J. Distance Educ. 2020, 31-44. [CrossRef]

129. Stuij, S.M.; on behalf of the INSTRUCT Project Group; Drossaert, C.H.C.; Labrie, N.H.M.; Hulsman, R.L.; Kersten, M.J.; Van Dulmen, S.; Smets, E.M.; De Haes, H. Developing a digital training tool to support oncologists in the skill of information-provision: A user centred approach. BMC Med. Educ. 2020, 20, 1-17. [CrossRef]

130. Sedra, M.; Bennani, S. Competency Based Approach: Modeling and Implementation. Int. J. Emerg. Technol. Learn. 2020, 15, 230-238. [CrossRef]

131. García-Peñalvo, F.J. Modelo de Referencia Para La Enseñanza No Presencial En Universidades Presenciales Reference Model for Virtual Education at Face-to-Face Universities. Campus Virtuales 2020, 9, 2020.

132. Shonfeld, M.; Magen-Nagar, N. The Impact of an Online Collaborative Program on Intrinsic Motivation, Satisfaction and Attitudes towards Technology. Technol. Knowl. Learn. 2017, 25, 297-313. [CrossRef]

133. Martin, I. Pronunciation Development and Instruction in Distance Language Learning. Lang. Learn. Technol. 2020, 24, 86-106.

134. Vershitskaya, E.R.; Mikhaylova, A.V.; Gilmanshina, S.I.; Dorozhkin, E.M.; Epaneshnikov, V.V. Present-day management of universities in Russia: Prospects and challenges of e-learning. Educ. Inf. Technol. 2019, 25, 611-621. [CrossRef] 
135. Andoh, R.P.K.; Appiah, R.; Agyei, P.M. Postgraduate Distance Education in University of Cape Coast, Ghana: Students' Perspectives. Int. Rev. Res. Open Distrib. Learn 2020, 21, 118-135. [CrossRef]

136. Al Said, N. Mobile Application Development for Technology Enhanced Learning: An Applied Study on the Students of the College of Mass Communication at Ajman University. Int. J. Emerg. Technol. Learn. 2020, 15, 57-70. [CrossRef]

137. Ramlatchan, M.; Watson, G.S. Enhancing instructor credibility and immediacy in online multimedia designs. Educ. Technol. Res. Dev. 2019, 68, 511-528. [CrossRef]

138. Joiner, K.; Rees, L.; Levett, B.; Sitnikova, E.; Townsend, D. Efficacy of structured peer critiquing in postgraduate coursework. Stud. High. Educ. 2020, 1-17. [CrossRef]

139. Villalpando, A.J.; Kanagusiko, A.G.; Flores, C.M.; Carrillo, J.M.; Mendoza, J.A.; Contreras, L.C.A.; Quiroz-Rivera, S. Motivación hacia las matemáticas de estudiantes de bachillerato de modalidad mixta y presencial. Rev. Educ. 2019, 23. [CrossRef]

140. Faisal, P.; Kisman, Z. Information and communication technology utilization effectiveness in distance education systems. Int. J. Eng. Bus. Manag. 2020, 12, 1-9. [CrossRef]

141. Jones, D.; Lotz, N.; Holden, G. A longitudinal study of virtual design studio (VDS) use in STEM distance design education. Int. J. Technol. Des. Educ. 2020, 1-27. [CrossRef]

142. Delnoij, L.E.; Dirkx, K.J.; Janssen, J.P.; Martens, R.L.; Laurie, E.D.; Kim, J.D.; Janssen, J.; Rob, L.M. Predicting and resolving non-completion in higher (online) education-A literature review. Educ. Res. Rev. 2020, 29, 100313. [CrossRef]

143. Prasandy, T.; Nurlaila, I.; Titan, T.; Lena, L. Implementation of "ADAB" to Hearing Impaired Student as Learning Innovation in the Data and Text Mining Course, Information System Distance Learning, Binus Online Learning. Int. J. Emerg. Technol. Learn. 2020, 15, 193-201. [CrossRef]

144. Corsby, C.L.T.; Bryant, A. "I felt like I was missing out on something": An evaluation of using remote technology in the classroom. Educ. Inf. Technol. 2020, 1-18. [CrossRef]

145. Amin, M.R.B.M.; Piaralal, S.K.; Bin Daud, Y.R.; Bin Mohamed, B. An Empirical Study on Service Recovery Satisfaction in an Open and Distance Learning Higher Education Institution in Malaysia. Int. Rev. Res. Open Distrib. Learn. 2020, 21, 36-60. [CrossRef]

(C) 2020 by the authors. Licensee MDPI, Basel, Switzerland. This article is an open access article distributed under the terms and conditions of the Creative Commons Attribution (CC BY) license (http://creativecommons.org/licenses/by/4.0/). 